
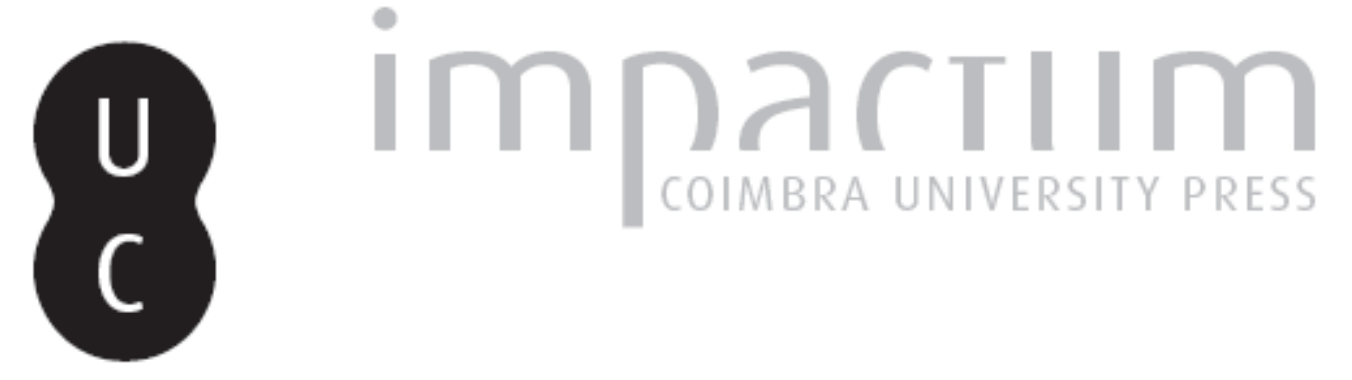

\title{
Financial constraints and exports: an analysis of portuguese firms during the european monetary integration
}

\author{
Autor(es): $\quad$ Silva, Filipe; Carreira, Carlos
}

Publicado por: Faculdade de Economia da Universidade de Coimbra

URL persistente:

URI:http://hdl.handle.net/10316.2/25217

DOI:

DOI:http://dx.doi.org/10.14195/2183-203X_34_2

Accessed : $\quad$ 26-Apr-2023 14:20:30

A navegação consulta e descarregamento dos títulos inseridos nas Bibliotecas Digitais UC Digitalis, UC Pombalina e UC Impactum, pressupõem a aceitação plena e sem reservas dos Termos e Condições de Uso destas Bibliotecas Digitais, disponíveis em https://digitalis.uc.pt/pt-pt/termos.

Conforme exposto nos referidos Termos e Condições de Uso, o descarregamento de títulos de acesso restrito requer uma licença válida de autorização devendo o utilizador aceder ao(s) documento(s) a partir de um endereço de IP da instituição detentora da supramencionada licença.

Ao utilizador é apenas permitido o descarregamento para uso pessoal, pelo que o emprego do(s) título(s) descarregado(s) para outro fim, designadamente comercial, carece de autorização do respetivo autor ou editor da obra.

Na medida em que todas as obras da UC Digitalis se encontram protegidas pelo Código do Direito de Autor e Direitos Conexos e demais legislação aplicável, toda a cópia, parcial ou total, deste documento, nos casos em que é legalmente admitida, deverá conter ou fazer-se acompanhar por este aviso.

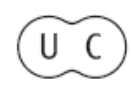


ANA SARGENTO / PEDRO NOGUEIRA RAMOS / GEOFFREY HEWINGS

FILIPE SILVA / CARLOS CARREIRA
INPUT-OUTPUT MODELLING BASED ON TOTAL-USE RECTANGULAR TABLES: IS THIS A BETTER WAY?

FINANCIAL CONSTRAINTS AND EXPORTS: AN ANALYSIS OF PORTUGUESE FIRMS DURING THE EUROPEAN MONETARY INTEGRATION 


\section{Financial Constraints and Exports: An Analysis of Portuguese Firms During the European Monetary Integration* \\ Filipe Silva / Carlos Carreira Faculdade de Economia / GEMF, Universidade de Coimbra}

abstract

Financial constraints are a key determinant that hinders firms' ability to export. This paper analyses the nexus between these constraints and firms' engagement in international trade, as well as it explores the impact of the European monetary integration process upon firms' financial constraints. Therefore, we estimate cash to cash-flow sensitivities for different periods (1996-2000 and 20012004) and different groups of firms, according to their exporting and importing activity. Our results indicate that, depending on their international openness, the European monetary integration seems to have generally helped reducing the degree of financial constraints faced by Portuguese firms. Additionally, our findings suggest that rather than unconstrained firms selfselecting into exporting firms' constraints were reduced after they started exporting. resumo

As restrições financeiras são um factor fundamental que inibe as exportações das empresas. Este texto analisa estas relações, bem como o impacto da Integração Monetária Europeia nas restrições ao financiamento das empresas. Para este efeito, estimámos a sensibilidade da liquidez ao cash-flow em períodos distintos (1996-2000 e 2001-2004) e para diferentes empresas, segundo a sua actividade exportadora e importadora. Os resultados indicam que a Integração Monetária Europeia reduziu o nível de restrições financeiras das empresas portuguesas, apesar deste efeito ter sido desigual para empresas consoante o seu grau de abertura ao exterior. Por fim, os resultados sugerem que ao invés de apenas empresas sem restrições ao financiamento serem capazes de exportar, estas restrições diminuem com o inicio da actividade exportadora.

JEL Classification: F14, F36, G32.

\footnotetext{
* Acknowledgments: We thank the Editor and an anonymous referee for their helpful comments and suggestions. Financial support from FCT (Portuguese Science Foundation) and GEMF is greatly appreciated. Filipe Silva would like to thank the financial support provided by FCT through the doctoral grant SFRH/BD/44067/2008 (POPH/FSE program).
} 
The causality between financial constraints and openness to foreign markets is rather unclear. On the one hand, open firms may have access to foreign finance and, especially if they are strong exporters, see their domestic credit conditions improve. On the other, these firms may only export because they were able to overcome the financial constraint barriers. Effectively, there are additional costs to explore foreign markets and the required investment may be financially constrained. As a result, only firms that are not financially constrained are able to export.

This paper explores how financial constraints relate to the openness of firms to foreign markets, in particular to their exporting and importing activities. Additionally, it evaluates the changes in firms' levels of constraints driven by a monetary integration process (the European Common Currency). While we find an inverse relationship between export intensity and financial constraints, we cast some doubts on the argument stating that only unconstrained firms self-select into export behaviour. In fact, a priori constrained firms are also able to export and there are significant improvements in firms' ability to raise external funds once they start exporting. Furthermore, we argue that while in general the monetary integration reduced the constraints faced by Portuguese firms, these were affected differently depending on their importing and exporting activities.

After the accession to the European Economic Communities (now the European Union, EU) in 1986, Portugal experienced not only the creation of the Common Market in 1992, but most of all the introduction of the Common Currency in 2001. The monetary integration that culminated in the Euro brought several changes, of which we should point out the reduction of interest rates (annualised benchmark interest rate fell from $7.2 \%$ in 1996 to $2.1 \%$ in 2004) ( $^{1}$ and the promotion of deeper integration of financial markets within the Euro area. Not only could economic agents obtain finance in the Euro area cheaper and in an easier manner, but also the adoption of a stronger currency has eased the access of Portuguese firms to foreign finance.

This paper is the first, to our knowledge, to analyse the effects of the European Monetary Integration on firms' ability to raise external funds. Additionally, along with the recent text of Silva (2011b), it is the first to analyse the relationship between openness to foreign markets, exports and firms' constraints for Portugal. Furthermore the relatively large time span of our unique dataset (see Silva and Carreira, 2010) allows us to compare two distinct periods (before and after monetary integration), which, as far as we know, is novel in the analysis of financial constraints at the firm level².

The importance of this paper with respect to policy making seems also worthwhile mentioning. On the one hand, it provides insights on the effects that monetary integrations have upon firms financial constraints, which is relevant not only to understand the subsequent behaviour of Portuguese firms after the introduction of the Euro, but also for policymakers in countries now joining the Common Currency. On the other, the clarification of the relationship between constraints, degree of openness and, most importantly, export activity, provides further evidence that is crucial to devise the adequate incentives to alleviate constraints and ultimately foster exports.

The paper is organized as follows. Section 2 makes a brief discussion of the literature on financial constraints, firms' exports and monetary integration. In Section 3 we discuss the dataset. Section 4 describes our empirical methodology, while Section 5 presents the main results. Finally, Section 6 pulls the pieces together and concludes.

1 Annualised Euribor and Lisbor at 3 months with adjusted Lisbor by the mean difference in common years (see Appendix for details).

2 Focusing on firm size issues and using different datasets, Cabral and Mata (2003) and Oliveira and Fortunato (2006) have also analyzed the role of financial constraints. The former use entrepreneurs' age as a proxy for wealth (ultimately for financial constraints) to analyse the evolution of firm size distribution; the latter estimate the impact of cash-flow upon firm employment growth (significant cash-flow coefficients are usually regarded as indicating the presence of financial constraints). 


\subsection{Measuring financial constraints}

The abstract nature of the concept of financial constraints (albeit for subjective firm selfevaluation, it is not directly measurable) has challenged researchers, mostly on empirical grounds, to consistently measure these constraints. In fact, even on theoretical grounds, it is difficult to come up with a clear-cut definition of financial constraints. If on the one hand, we can broadly say that financial constraints exist whenever there is a wedge between the costs of obtaining internal and external funds - following Kaplan and Zingales's (1997) definition that virtually covers every firm -, on the other, we prefer to define financial constraints as the inability of a firm to raise the necessary amounts (usually due to external finance shortage) to finance their investment and growth.

Despite theoretical literature identifies difficulties in the access of firms to external funds, empirically there is no consensus on how to measure financial constraints (see Hubbard, 1998 or Carreira and Silva, 2010 for a discussion). While some authors may resort to the primordial Fazzari, Hubbard and Petersen (1988) measure of Investment-Cash Flow Sensitivities (e.g. Bond et al., 2003), others check if parameter restrictions of a derived reduced form Euler equation for investment, based on Whited (1992), are satisfied (e.g. Harhoff, 1998).

Recently, analyzing firm's demand for cash, Almeida et al. (2004) advance that the level of financial constraints can be measured by the sensitivity of cash to cash-flows (CCFS). They argue that only constrained firms will manage liquidity to maximize their value. The rationale behind is that while constrained firms need to save cash out of cash flows in order to take advantage of future investment opportunities, unconstrained firms do not, as they are able to resort to external finance. Meanwhile, firms that hold cash incur in opportunity costs associated with present investment opportunities. As a result, only constrained firms will need to optimize their cash stocks along the time, in order to maximize their profits and hedge against future shocks. Therefore, one can expect that estimates on the sensitivity of cash stocks to cash-flow would be positive and significant for constrained firms, while no such relation should be expected for unconstrained ones. In fact, Hahn (2010) supports that holding liquid assets may work as a good hedging policy for firms, when there are imperfections in financial markets. To our knowledge, only a few works have used this approach so far (see Silva and Carreira, 2010 for details).

Finally, other strategies include the construction of indexes based on variables that are generally agreed to be good proxies of constraints or, if data is available, resort to the subjective firms' selfevaluation of constraints (see Carreira and Silva, 2010).

\subsection{Financial constraints, trade and monetary integration}

Financial constraints seem to be an important factor to take into account when analysing international trade, as suggested, for example, by the theoretical models of Chaney (2005), Manova (2010) and Broll and Wahl (2011). These models are based on Melitz (2003), that already recognizes the importance of fixed costs when firms decide to export. However, in such models, financial constraints are seen as an exogenous barrier to export, even though we provide evidence that firms that start exporting experience a reduction in constraints. Shipping goods across countries may entail significant additional costs than selling them in the domestic market, not to mention jurisdiction differences between countries (Bekaert and Hodrick, 2008). Even though one should expect a negative relationship between financial constraints and exports, it is not clear whether exporting reduces financial constraints or unconstrained firms self-select into exporting. On the one hand, start exporting may lead to more stable cash-flows due to sales diversification, that hedge against demand side shocks (Bridges and Guariglia, 2008). Moreover, exporting may signal efficiency to investors (Ganesh-Kumar et al., 2001), not to mention that such firms may additionally gain access to foreign finance. On the other hand, firms face significant sunk costs when they start exporting, thus financial constraints may work as a major barrier to 
export activity. In fact, Bellone et al. (2010), for French firms, find that financial constraints work as an ex-ante barrier to export, since less constrained firms self-select into exporting behaviour. Examples of this self-selection effect can also be found in Greenway et al. (2007) for the UK, Manole and Spatareanu (2010) for the case of Czech firms, Forlani (2010) and Minetti and Zhu (2011) for Italian firms or in Berman and Hericourt (2010) for 9 developing and emerging economies. Therefore, if financial constraints work as a major barrier to export then, in order to foster exports, incentives particularly designed to alleviate such constraints are certainly warranted ${ }^{3}$. Recently, for the Portuguese case, Silva (2011b) analyses firms financial condition prior to export and uses an index of constraints based on Bellone et al. (2010) as dependent variable for treatment effects estimation of the impact of exports upon financial constraints. His results support that not only there is a self-selection effect, but also that such constraints are reduced once firms engage in exporting activity.

When it comes to financial development and integration, while previous empirical literature, in general, found that it alleviates firms' financial constraints (Carreira and Silva, 2010), recent studies analysing the impact of financial crises, put these results into perspective. As an example, Popov and Ongena (2011), comparing both Western and Central with Eastern European countries, find that interbank market integration has reduced the level of constraints, especially in highly competitive banking sector markets. However, there were significant risks of overleveraging when integration took place at an accelerated pace. Nonetheless, Amiti and Weinstein (2009), for Japan, find that financial constraints severely affect exporting activity during financial crisis, while Chor and Manova (2011), using US imports data find that, during the recent financial crisis, higher interbank interest rates led to lower exports especially for firms in more financially constrained sectors. For the European case, we should also stress that monetary integration came along, among others, with the loss monetary policy instruments. Still, the levels of financial constraints seem to be lower in bank-based systems (see Carreira and Silva, 2010 for a survey or Hernández-Cánovas and Martínez-Solano, 2010 for an example), especially for short-term finance (Kunt and Maksimovic, 2002). Gorg and Spaliara (2009), comparing firms operating in the UK and France, find that firm failure is more sensible to financial variables for firms in the "market-oriented system» of the UK. Additionally, they find that continuous export behaviour increases firm survival.

Overall, not only there is still much to be said with respect to the causality flows between financial constraints and degree of openness, but also the real benefits of the European monetary integration process are, still nowadays, rather unclear and very debatable. Specifically, despite the extensive literature on firm's financial constraints, the consequences of such processes upon the ability of firms to raise the necessary amounts to invest, grow and export are still to be fully explored. Keeping in mind that no consistent measure of financial constraints has yet been developed, we test the following hypothesis: i) Monetary integration alleviates financial constraints and benefits mostly open firms; ii) Financially unconstrained firms self-select into exporting activity. Inferences using this sample, representative of Portuguese firms, may be made with respect to, at least, other bank-based economies.

\section{Data}

The dataset used in this work was constructed from the combination of Inquérito às Empresas Harmonizado (IEH), an annual business survey, and Ficheiro de Unidades Estatísticas (FUE), both collected by the Portuguese National Statistical Office (INE). The former dataset comprises information on firms' balance sheets, while resorting to the latter, that contains information about firm's generic characteristics - including size, age and main sector of activity -, allows to track firms trough time, thus constructing a large unbalanced panel of firms ${ }^{4}$.

3 Note that, for the Portuguese case, Silva (2011a) finds that production subsidies neither significantly increase the probability that firms start to export nor increase their export intensity, even though production subsidies may not be particularly designed to foster exports, as the author argues.

4 These two data sources were matched using a code number, also provided by INE, that uniquely identifies each firm for different surveys along the successive years. 
For the purpose of this paper the following cleaning procedures were made. First, we eliminated firms with less than 20 employees due to the lack of quality of information reported by such firms. Second, we focus only on the industry and part of the services sector, thus eliminating the agricultural and financial sectors (the latter would bias the estimation favouring unconstrained firms). Observations that were reported either missing or with unreasonable values were dropped $^{5}$. As a result we have a large unbalanced panel of 22.651 firms for the period 19962004 resulting in 86.455 observations. Further details on the construction and description of the variables used are available in the Appendix.

The advantage of using this dataset is that it comprises information from firm's balance sheets for the universe of firms operating in Portugal with more than 100 employees and a large representative sample of Portuguese firms with more than 20 employees. The final dataset is representative of the Portuguese economy, covering all sectors and industries of economic activity (with the exceptions previously outlined). Finally, the large sample period (1996-2004) is sufficient to take into account macroeconomic cyclical variations as well as it covers the monetary integration process.

However, a major pitfall of this dataset is the inexistence of market information about firms. Since we only have access to a code number of each firm, we are not able to match the dataset with information from, for example, stock markets. Still, only a few firms in Portugal are publicly traded (most of them within the financial sector), hence the benefits of such extension of the dataset would be negligible. Additionally, information on firms is limited to a relatively low level of disaggregation of balance sheets. Finally, by dropping from the database all firms with less than 20 employees, we are cutting off a significant number of observations. Even though information on these firms lacks in quality and further increases the unbalancedness of the panel, smaller firms would, a priori, be more financially constrained (e.g. Cabral and Mata, 2003 or Oliveira and Fortunado, 2006, both for the Portuguese case). Consequently, our results might be slightly downward biased when it comes to the level of firms' financial distress. Nevertheless, such firms are typically closed (see section 5.1 for the relationship between size and openness), therefore they would not influence the analysis on exporting and importing activities.

\section{Methodology}

Almeida et al. (2004) construct an alternative model of liquidity demand and derive an empirical equation to estimate CCFS. The financial nature of the cash stock variable is a shield against missmeasurements in Tobin's Q (usual control for investment opportunities) and investment opportunities hidden in cash-flow because it is not expected that firms will increase their cash stocks if cash-flow signals a new $/$ better investment opportunity, unless they are financially constrained. However, as pointed by Acharya et al. (2007), financially constrained firms will only use cash to increase cash stocks if hedging needs are high (investment opportunities), otherwise they use cash to reduce debt. Therefore, we control both for debt issuances as well as for investment opportunities. Additionally, as pointed by Almeida et al. (2011) in a subsequent paper, cash may not be the only way to transfer resources across time, since firms may invest in relatively liquid assets, other than cash. As a result, we try to control for this effect through investment in non-cash net working capital and financial investments.

Keeping these caveats in mind, we follow of Lin (2007) and use the sum of net debt and equity issuances $\left(I S S_{i, t}\right)$, as well as interest rate variation, instead of the variation of short-term deb. The former modification is due to the fact that debt and equity issuances, while being a signal of easier access to external funds, might have a significant impact upon cash stocks (by accounting procedures), so we control for such effect. With respect to the latter, firms may decide to reduce their borrowings or pay back debt according to expected interest expenses. However, instead of 
benchmark interest rate variation, in our baseline specification we use variations of interest paid $\left(\Delta I N T_{i, t}\right)$, which allows for firm heterogeneity and thus can also be seen as a form of credit rating. Furthermore, we also control for financial investments $\left(\boldsymbol{F i n I}_{i, t}\right)$, that not only are a demand for cash but may also work as an alternative way to transfer resources across time. In both specifications, all variables are scaled by total assets (except the control for firm size). As a result, we have the following empirical specification:

$\Delta C S_{i, t}=\beta_{0}+\beta_{1} C F_{i, t}+\beta_{2} \Delta y_{i, t}+\beta_{3} S_{i, t}+\beta_{4} I_{i, t}+\beta_{5} \Delta N W C_{i, t}+\beta_{6} I S S_{i, t}$

$+\beta_{7} \Delta I N T_{i, t}+\beta_{8}$ FinI $_{i, t}+d_{k}+\varepsilon_{i, t}$

where $\Delta \boldsymbol{C} \boldsymbol{S}_{i, t}$ is the variation in cash stocks of firm $i$ in period $t, \boldsymbol{C F}_{i, t}$ the cash-flow, $\boldsymbol{S}_{i, t}$ is a control for firm size (log of total assets), $\boldsymbol{I}_{i, t}$ investment, $\Delta N W C_{i, t}$ is the variation of noncash net working capital, $\boldsymbol{d}_{\boldsymbol{k}}$ are two-digit industry dummies (CAE rev. 2.1) and $\varepsilon_{i, t}$ the error term. We do not have financial markets information that would allow us to compute Tobin's $Q$. Therefore, we use sales growth $\left(\Delta y_{i, t}\right)$ to proxy investment opportunities. This measure is often used in empirical work on countries with less developed financial markets where information on firm's market value is scarcer (see for eg. Budina et al., 2000 or Konings et al., 2003). Additionally, the use of Tobin's Q is also methodologically questionable. Firstly, marginal $Q$ is unobservable, so researchers use average $Q$ as a proxy - see Hayashi (1981) for the derivation of average Q. Secondly, the introduction of $Q$ directly into the estimation of investment models for the purpose of analysing financial constraints may cause the sensitivities to cash-flows to be overestimated, as they might contain information about investment opportunities that were not captured by Q - Alti, 2003, in a model where financial frictions are absent, shows that, even after $Q$ correction, firms exhibit sensitivities to cash-flow.

The financial and investment covariates are endogenous, so we estimate the model using instrumental variables (IVGMM) with fixed effects to take account of unobserved firm-level heterogeneity and panel-robust standard errors. The set of instruments includes twice lagged cash flow, twice lagged sales growth, lagged investment, lagged variation of noncash net working capital, number of employees, lagged bond issuance and lagged variation in interest payments ${ }^{6}$.

In an attempt to capture the effects of monetary and financial integration, we split our sample into two major periods, before and after integration (i.e. up to 2000 and from 2001 onwards). Even though the integration processes is continuous, we pick this breakpoint for two main reasons. First, we only have access to the period 1996-2004, consequently, to guarantee a consistent estimation that takes advantage of lagged variables, we must guarantee that the subpanels have at least a 3 year depth (preferably 4 year to have a larger number of observations for a more efficient estimation) ${ }^{7}$. Accordingly, our breakpoint should be either on 1999 or 2000 . Second, since the Euro was introduced on the $1^{\text {st }}$ January 2001, a landmark for the monetary integration process, we expect that the possible benefits would be observed from 2001 onwards. Additionally, it is reasonable to expect that the real effects of the potential benefits from the ongoing integration process before 2001 would be subject to a «policy lag», therefore only having a significant impact on firms during the subsequent period. As a result, we expect that the bulk impact of the integration process would be felt during the period 2001-2004 ${ }^{8}$.

6 Note that if the methodology is applied to a large number of observations, coefficients are usually found to be statistically significant, since the precision of the estimate is higher. However, one should still expect that such coefficients are higher for financially constrained groups of firms. Comparison of CCFS estimates with other studies can be found in Silva and Carreira (2010).

7 The limitation of the period of analysis (1996-2004) is due to methodological changes on the collection of data by INE.

8 Note that this second period not only captures a downward economic cycle, but it also corresponds to higher bilateral exchange rates (convergence was before 2001 but effects might be time lagged) which affects the capacity of firms to export and import (although very debatable, degree of openness should account for this 
In order to capture the effects of integration upon financial constraints by different classes of firms, according to their degree of openness to foreign markets, we construct a score that identifies firms as closed, open and, within open firms, those with low and high levels of openness (see Appendix for further detail). Consequently, we obtain different subsamples of firms depending on their exposure to European markets. Over the period, the EU, on average, accounts for $75 \%$ of the total exports and $89 \%$ of imports. As a result, we focus mainly on the degree of openness towards the EU. In fact, the results using a broader definition that covers total exports and imports remain unchanged ${ }^{9}$. The same procedure is made with respect to exports and imports, that we then classify as levels of export and import intensity, respectively. With the purpose of comparing the CCFS estimates across subsamples, we compute the confidence intervals and perform formal Wald tests ${ }^{10}$. The robustness of the inverse relationship between financial constraints, degree of openness, export and import intensities is checked by introducing interaction terms between cash-flow and these variables (Table A1 in appendix).

Finally, in order to compare firms' constraints before and after shifting into open, exporting or importing activity, we group firms that moved from closed to open, started exporting and importing, respectively. We further divide the period of time, for each firm, according to the moment they shifted.

\section{Empirical results}

\subsection{Summary statistics}

Table 1a allows us to compare mean values, before and after monetary integration as well as by degree of openness, of the main variables used in the estimation. It is clear that after monetary integration mean variation of cash stocks and size (total assets) increased during the period, while mean cash-flow, sales growth, investment, debt and equity issuances, benchmark interest rate and degree of openness decreased (columns 2 and 3$)^{11}$. Additionally, while firms faced a mean decrease in interest paid, the mean variation in non cash net working capital increased. If instead we compare different levels of openness, it is possible to see that, for the whole period, differences between less open and highly open firms (columns 5 and 6) are, in general, larger than differences between closed and slightly open firms (columns 4 and 5 ). This indicates that firms with no or a low level of openness appear to be quite similar. However, when we further distinguish between levels of export and import intensity (Table 1b, columns 1-3 and 4-6, respectively), this pattern is not as clear. While firms with higher levels of both import and export intensity are larger and face both lower cash stock variation and higher cash-flows (which should be expected at least for heavy exporters and might be a sign of lower constraints), intensive exporters are distinct from intensive importers when it comes to sales growth. In fact, while for higher levels of export intensity firms face lower sales growth, the opposite is true for higher levels of import intensity. This is rather puzzling, in particular for the case of exporters, since we would expect that sales would increase with higher levels of export intensity, even though it may well depend upon economic growth abroad. This odd result is also evident when we compare firms before and after they shifted into exporting or importing (columns $7-10)^{12}$. In addition, for both of these groups of firms, they face larger cash stocks variation and lower cash-flows, once they shifted, which is in contrast with the statistics found for different intensities.

inverse sign effects). Conversely, the previous period, not only captures an economic expansion period, but also carries the effects of the implementation of the Common market in 1992. This latter effect is, however, expected to be transversal to the whole period.

9 Statistics not reported but available from authors upon request.

10 For simplicity, we omit confidence intervals and test statistics (available from the authors on request) and only report if estimates were found to be statistically different or not.

11 We should note that the economic downturn that came after 2001 may be affecting, to a larger extent some of these variables (e.g. exports or sales growth).

12 Nevertheless, this is in line with the downward economic cycle that came after 2001, which, for the

Portuguese case, is clear from the reduction in sales growth in the second major period of analysis (Table 1a). 


\begin{tabular}{|c|c|c|c|c|c|c|}
\hline \multirow{3}{*}{ VARIABLES } & \multicolumn{3}{|c|}{ Period } & \multicolumn{3}{|c|}{ Degree of Openness } \\
\hline & 1996-2004 & $1996-2000$ & $2001-2004$ & NO & LOW & HIGH \\
\hline & (1) & (2) & (3) & (4) & (5) & (6) \\
\hline \multirow[t]{2}{*}{$\Delta C S_{i, t}$} & 0.002 & 0.001 & 0.003 & 0.003 & 0.003 & 0.001 \\
\hline & $(0.062)$ & $(0.064)$ & $(0.061)$ & $(0.070)$ & $(0.055)$ & (0.059) \\
\hline \multirow[t]{2}{*}{$C F_{i, t}$} & 0.085 & 0.091 & 0.081 & 0.083 & 0.082 & 0.089 \\
\hline & $(0.089)$ & $(0.089)$ & $(0.088)$ & $(0.098)$ & $(0.085)$ & $(0.083)$ \\
\hline \multirow[t]{2}{*}{$\Delta y_{i, t}$} & 0.037 & 0.073 & 0.015 & 0.040 & 0.041 & 0.030 \\
\hline & $(0.288)$ & $(0.280)$ & $(0.290)$ & $(0.326)$ & $(0.269)$ & $(0.264)$ \\
\hline \multirow[t]{2}{*}{$S_{i, t}$} & 15.539 & 15.441 & 15.599 & 15.074 & 15.698 & 15.840 \\
\hline & $(1.448)$ & $(1.508)$ & $(1.406)$ & (1.508) & (1.476) & (1.237) \\
\hline \multirow[t]{2}{*}{$I_{i, t}$} & 0.063 & 0.077 & 0.054 & 0.068 & 0.061 & 0.060 \\
\hline & $(0.081)$ & $(0.091)$ & $(0.074)$ & $(0.090)$ & $(0.077)$ & $(0.076)$ \\
\hline \multirow[t]{2}{*}{$\Delta N W C_{i, t}$} & -0.048 & -0.060 & -0.040 & -0.051 & -0.046 & -0.047 \\
\hline & $(0.166)$ & $(0.179)$ & $(0.157)$ & $(0.189)$ & $(0.155)$ & $(0.152)$ \\
\hline \multirow[t]{2}{*}{$I S S_{i, t}$} & 0.035 & 0.058 & 0.021 & 0.036 & 0.037 & 0.032 \\
\hline & $(0.209)$ & $(0.218)$ & $(0.203)$ & $(0.227)$ & $(0.201)$ & (0.198) \\
\hline \multirow[t]{2}{*}{$\operatorname{FinI}_{i, t}$} & 0.039 & 0.038 & 0.040 & 0.039 & 0.042 & 0.036 \\
\hline & $(0.088)$ & $(0.086)$ & $(0.090)$ & (0.096) & $(0.090)$ & (0.079) \\
\hline \multirow[t]{2}{*}{$\Delta I N T_{i, t}$} & -0.001 & 0.000 & -0.001 & -0.000 & -0.000 & -0.001 \\
\hline & $(0.007)$ & $(0.008)$ & $(0.007)$ & $(0.008)$ & $(0.007)$ & $(0.007)$ \\
\hline \multirow[t]{2}{*}{$R$} & 0.030 & 0.037 & 0.026 & & & \\
\hline & $(0.008)$ & $(0.007)$ & $(0.005)$ & & & \\
\hline \multirow[t]{2}{*}{ OPEN } & 0.125 & 0.134 & 0.119 & & & \\
\hline & $(0.175)$ & $(0.180)$ & $(0.171)$ & & & \\
\hline Observations & 17,283 & 6,600 & 10,683 & 5,757 & 5,444 & 6,066 \\
\hline N. of firms & 4,771 & 2,606 & 3,333 & 1,537 & 1,462 & 1,632 \\
\hline
\end{tabular}

Notes: Mean values and standard deviations, given in parentheses, of the main variables used in the estimations. Some of the statistics in this table were reported in Silva and Carreira (2011)

Table $1 c$ reports the Spearman's correlation coefficients for the main variables used and by different sub-periods ${ }^{13}$. Firstly, we should point that the positive association between cash-flow and both changes in cash stocks and investment is slightly larger for the first period, which may provide the first insights on possible differences in CCFS (as well as ICFS) ${ }^{14}$. Secondly, we should highlight that whereas in the first period there is a significant positive correlation between the benchmark interest rate and sales growth, this association is negative and significant in the second period (which may well result from the economic cycle). Meanwhile, the correlation

13 We avoid using Pearson's correlation coefficients due to the non-normality of a large number of variables. 14 We test the alternative ICFS methodology and in fact results point to larger sensitivities in the first period ( 0.61 against 0.23 , significant at $5 \%$ level). Statistics not reported but available from authors on request. 


\begin{tabular}{|c|c|c|c|c|c|c|c|c|c|c|}
\hline \multicolumn{11}{|c|}{ TABLE 1b - Summary Statistics } \\
\hline \multirow{3}{*}{ VAR. } & \multicolumn{6}{|c|}{ Period } & \multicolumn{4}{|c|}{ Degree of Openness } \\
\hline & NO & LOW & HIGH & NO & LOW & HIGH & Before & After & Before & After \\
\hline & (1) & (2) & (3) & (4) & $(5)$ & (6) & (7) & (8) & (9) & (10) \\
\hline \multirow[t]{2}{*}{$\Delta C S_{i, t}$} & 0.004 & 0.003 & 0.000 & 0.003 & 0.002 & 0.002 & 0.001 & 0.003 & 0.000 & 0.003 \\
\hline & $(0.067)$ & $(0.055)$ & $(0.058)$ & $(0.069)$ & $(0.057)$ & $(0.058)$ & $(0.057)$ & $(0.055)$ & $(0.058)$ & $(0.056)$ \\
\hline \multirow[t]{2}{*}{$C F_{i, t}$} & 0.083 & 0.085 & 0.088 & 0.081 & 0.083 & 0.091 & 0.094 & 0.085 & 0.089 & 0.081 \\
\hline & $(0.095)$ & $(0.081)$ & $(0.084)$ & $(0.096)$ & $(0.085)$ & $(0.082)$ & $(0.086)$ & $(0.084)$ & $(0.084)$ & $(0.084)$ \\
\hline \multirow[t]{2}{*}{$\Delta y_{i, t}$} & 0.045 & 0.033 & 0.027 & 0.036 & 0.037 & 0.038 & 0.066 & 0.035 & 0.051 & 0.024 \\
\hline & $(0.313)$ & $(0.261)$ & $(0.266)$ & $(0.323)$ & $(0.271)$ & $(0.256)$ & $(0.292)$ & $(0.271)$ & $(0.272)$ & $(0.279)$ \\
\hline \multirow[t]{2}{*}{$S_{i, t}$} & 15.226 & 15.817 & 15.809 & 15.106 & 15.663 & 15.947 & 15.724 & 15.818 & 15.827 & 15.793 \\
\hline & $(1.540)$ & $(1.302)$ & $(1.301)$ & $(1.496)$ & $(1.450)$ & (1.229) & $(1.413)$ & $(1.414)$ & $(1.469)$ & $(1.434)$ \\
\hline \multirow[t]{2}{*}{$I_{i, t}$} & 0.067 & 0.056 & 0.062 & 0.066 & 0.060 & 0.062 & 0.074 & 0.054 & 0.067 & 0.056 \\
\hline & $(0.089)$ & $(0.075)$ & $(0.074)$ & $(0.088)$ & $(0.076)$ & $(0.077)$ & $(0.092)$ & $(0.072)$ & $(0.079)$ & $(0.079)$ \\
\hline \multirow[t]{2}{*}{$\Delta N W C_{i, t}$} & -0.050 & -0.039 & -0.051 & -0.050 & -0.049 & -0.044 & -0.053 & -0.039 & -0.048 & -0.047 \\
\hline & $(0.181)$ & $(0.148)$ & $(0.154)$ & $(0.187)$ & $(0.154)$ & $(0.149)$ & $(0.175)$ & $(0.168)$ & $(0.169)$ & $(0.167)$ \\
\hline \multirow{2}{*}{$I S S_{i, t}$} & 0.040 & 0.034 & 0.028 & 0.035 & 0.033 & 0.037 & 0.060 & 0.026 & 0.044 & 0.024 \\
\hline & $(0.222)$ & $(0.194)$ & $(0.200)$ & $(0.226)$ & $(0.202)$ & $(0.194)$ & $(0.222)$ & $(0.197)$ & $(0.230)$ & $(0.197)$ \\
\hline \multirow[t]{2}{*}{$\Delta I N T_{i, t}$} & -0.000 & -0.001 & -0.001 & -0.000 & -0.001 & -0.001 & -0.000 & -0.000 & -0.000 & -0.001 \\
\hline & $(0.008)$ & $(0.007)$ & $(0.007)$ & $(0.008)$ & $(0.007)$ & $(0.006)$ & $(0.008)$ & $(0.007)$ & $(0.008)$ & $(0.006)$ \\
\hline \multirow[t]{2}{*}{ FinI $_{i, t}$} & 0.040 & 0.037 & 0.040 & 0.039 & 0.043 & 0.036 & 0.042 & 0.049 & 0.048 & 0.049 \\
\hline & $(0.094)$ & $(0.082)$ & $(0.084)$ & $(0.094)$ & $(0.091)$ & $(0.078)$ & $(0.092)$ & $(0.105)$ & $(0.100)$ & $(0.108)$ \\
\hline Observ. & 8,039 & 4,315 & 4,913 & 6,652 & 5,066 & 5,550 & 990 & 990 & 1,302 & 1,302 \\
\hline N. of firms & 2,210 & 1,144 & 1,333 & 1,782 & 1,374 & 1,523 & 300 & 300 & 397 & 397 \\
\hline
\end{tabular}

Notes: Mean values and standard deviations, given in parentheses, of the main variables used in the estimations.

between benchmark interest rate and cash-stock variation is only significantly negative for the first period. This latter pattern is also verified when it comes to the correlation between exports and both cash stock variation and sales growth. Additionally, there is a strong positive association between size and both export and import intensity, suggesting that larger firms are those that export and import the most, which is not unexpected ${ }^{15}$. Furthermore, the extremely high and significant correlation between import and export intensities is also as expected and indicates that defining degree of openness as the combination of both is sensible. Finally, the positive correlation between cash-flow and both export and import intensity is higher and strongly significant for the second period, pointing to potentially larger benefits for international firms after the Monetary integration.

15 In fact, the correlation between size (total assets) and degree of openness is positive, high and statistically significant. The same is true if instead of total assets we use number of employees as a measure of size (spearman's rho is $0.23^{\star}$ ). Furthermore, for different size classes (with thresholds at 50, 100 and 250 employees) the mean degree of openness is $0.07,0.11,0.16$ and 0.17 for small, medium-small, medium-large and large firms, respectively. 


\section{$4 5 \longdiv { 1 }$}

TABLE 1C - Spearman's rank correlation coefficients for the different periods

\begin{tabular}{c|c|c|c|c|c|c|c|c|c|c|c|c|}
\hline 1996-2004 & $\Delta C S$ & CF & $\Delta y_{i, t}$ & S & I & $\Delta N W C$ & ISS & $\Delta I N T$ & FinI $_{i, t}$ & $\mathbf{R}$ & Export $/$ Import & Open
\end{tabular}

\begin{tabular}{|c|c|c|c|c|c|c|c|c|c|c|c|c|c|}
\hline$\Delta C S$ & 1.000 & & & & & & & & & & & & \\
\hline CF & $0.0830^{*}$ & 1.000 & & & & & & & & & & & \\
\hline$\Delta y_{i, t}$ & $0.1185^{*}$ & $0.2395^{*}$ & 1.000 & & & & & & & & & & \\
\hline $\mathrm{S}$ & -0.0012 & $-0.0539^{*}$ & $0.0386^{*}$ & 1.000 & & & & & & & & & \\
\hline I & $-0.0274^{*}$ & $0.3205^{*}$ & $0.1594^{*}$ & -0.0189 & 1.000 & & & & & & & & \\
\hline$\triangle N W C$ & $-0.2525^{*}$ & 0.0051 & $0.0248^{*}$ & $0.0518^{*}$ & $-0.2827^{*}$ & 1.000 & & & & & & & \\
\hline ISS & $0.1105^{*}$ & $-0.1433^{*}$ & $0.1740^{*}$ & $0.0437^{*}$ & $0.2043^{*}$ & 0.003 & 1.000 & & & & & & \\
\hline$\Delta I N T$ & -0.0089 & $-0.0742^{*}$ & $0.1246^{*}$ & 0.0164 & $0.0876^{*}$ & $0.0354^{*}$ & $0.2125^{\star}$ & 1.000 & & & & & \\
\hline FinI $_{i, t}$ & $-0.0218^{*}$ & $-0.0736^{*}$ & $-0.0324^{*}$ & $0.4043^{*}$ & $-0.0404^{*}$ & -0.0135 & 0.0065 & -0.0019 & 1.000 & & & & \\
\hline $\mathbf{R}^{i, t}$ & $-0.0307^{*}$ & $0.0360^{*}$ & $0.0888^{*}$ & $-0.0514^{*}$ & ${ }^{*} 0.1318^{\star}$ & $-0.0377^{*}$ & $0.0598^{\star}$ & $0.1180^{*}$ & -0.0054 & 1.000 & & & \\
\hline Export & -0.0202 & $0.0492^{*}$ & $-0.0254^{*}$ & $0.2135^{*}$ & $0.0260^{*}$ & -0.0028 & -0.0188 & $-0.0340^{*}$ & $0.0817^{\star}$ & 0.0121 & 1.000 & & \\
\hline Import & -0.0101 & $0.0507^{\star}$ & 0.0131 & $0.2876^{*}$ & 0.0130 & $0.0303^{*}$ & 0.0009 & -0.0199 & $0.0819^{*}$ & $0.0232^{*}$ & $0.5501^{*}$ & 1.000 & \\
\hline Open & -0.0170 & $0.0477^{*}$ & -0.0092 & $0.2581^{*}$ & 0.0145 & 0.0175 & -0.0083 & $-0.0281^{*}$ & $0.0761^{*}$ & $0.0239^{*}$ & $0.8256^{*}$ & $0.8619^{*}$ & 1.000 \\
\hline
\end{tabular}

\section{6-2000}

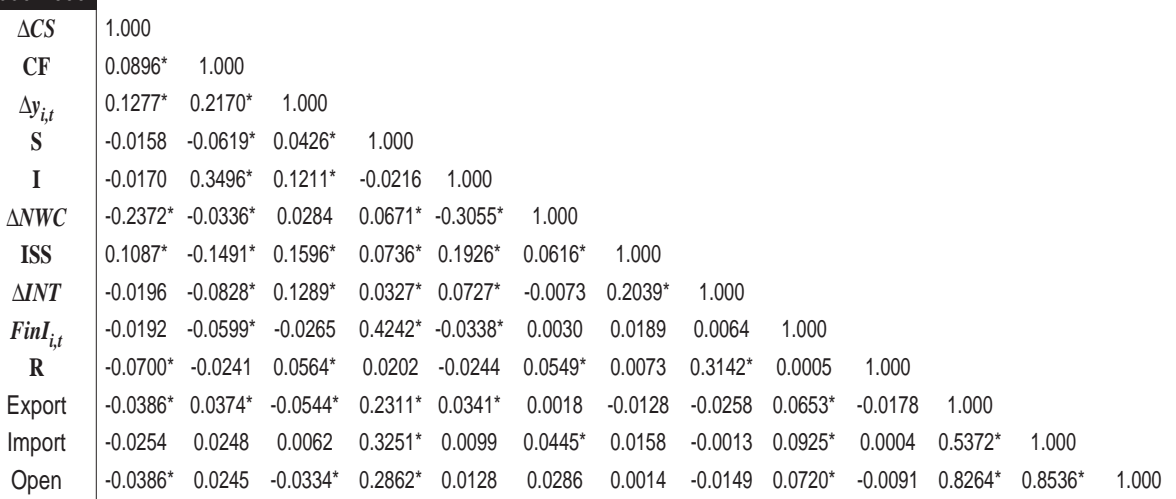

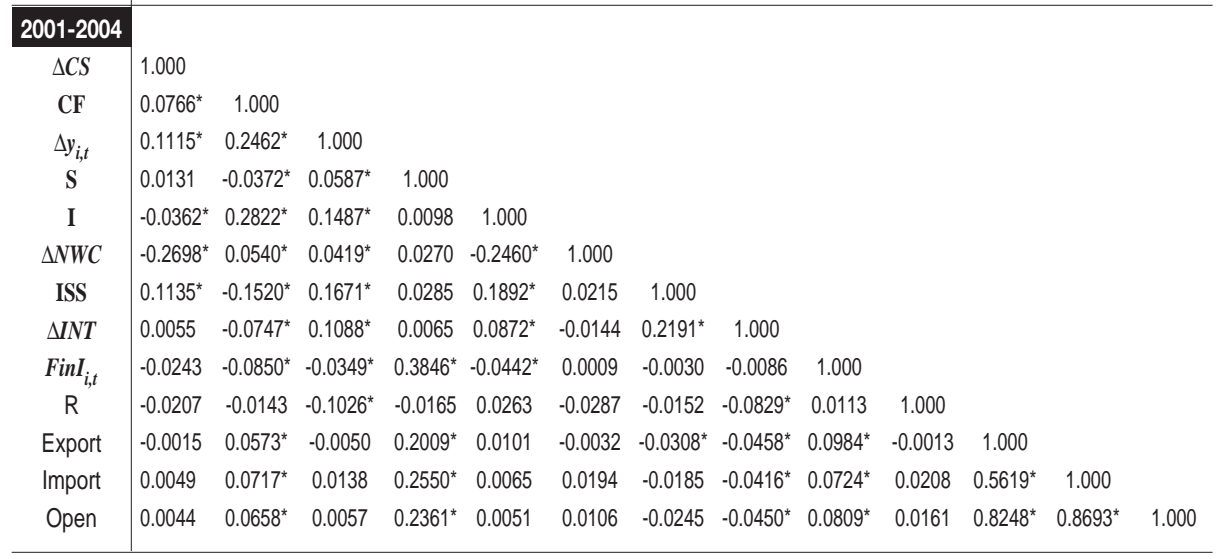

Notes: Rank correlation coefficients were calculated using Sidak's adjustment.

* denotes statistical significance at the .01 level. 


\subsection{Monetary integration}

Portuguese firms, during the period 1996-2004 were, on average, financially constrained. Table 2 shows that before monetary integration firms saved, on average, 25 cents out of each euro of cash flow, meanwhile after integration the CCFS was reduced to 0.183 (first line of columns 2 and 3 , respectively). A formal Wald test rejects the hypothesis that the CCFS coefficient after integration is the same as before integration, at the $95 \%$ level. If we abstain from controlling for the money market, the difference in CCFS is also large and statistically significant (columns 6 and 7) ${ }^{16}$. Noteworthy differences are also found with respect to the impact of sales growth, size, debt and equity issuances and interest payments variations in the cash policy of firms. The Euro landmark is further emphasized if year dummies are introduced (column 1). Even though a comparison between the two periods with year dummies is not econometrically feasible, in a regression over the whole period 1996-2004, only the dummy corresponding to 2000 is statistically significant ${ }^{17}$. This may indicate that, in this particular year, there were changes that significantly affected firms' cash policy. Alternatively, if we control for the evolution of the benchmark interest rate (columns 4 and 5), it is possible to observe that not only the CCFS difference between periods is much lower (and not statistically significant), but also that there is a huge difference in the impact of the benchmark interest rate between periods (negative for the first period and not different from zero in the second ${ }^{18}$. This result indicates that the evolution of interest rates (fell from $7.2 \%$ in 1996 to $2.1 \%$ in 2004), that mirrors the integration process, were an important determinant of firms' cash policy. Therefore, even if firms anticipated this effect, it helps in explaining the differences in CCFS between periods (columns 2-3 and 6-7) and supports the analysis distinguishing each period.

16 Silva and Carreira (2010) refer to a few benchmark CCFS coefficients from other studies.

17 The use of lagged variables both as independentlendogenous variables and instruments imposes that a number of year dummies must be dropped due to collinearity. However, we tested simpler regressions and results do not differ substantially. Namely, either d5 (2000) is the only significant dummy (always at $1 \%$ level) or dummies corresponding to previous years are slightly significant (at either $5 \%$ or $10 \%$ levels), while 2000 remains the most significant.

18 Note that the introduction of the benchmark interest rate, that is common to all firms - even though in practice firms are able to negotiate with banksllenders their own interest rate (the reason to use interest paid) implies that neither year dummies nor interest paid can be used in the estimation. 
TABLE 2 - CCFS estimation with different controls for money market

\begin{tabular}{|c|c|c|c|c|c|c|c|}
\hline \multirow{3}{*}{ VARIABLES } & \multirow{2}{*}{$\begin{array}{l}\text { Dummies } \\
1996-2004 \\
\end{array}$} & \multicolumn{2}{|c|}{ Baseline estimation } & \multicolumn{2}{|c|}{ Benchmark interest rate } & \multicolumn{2}{|c|}{ No controls } \\
\hline & & $1996-2000$ & 2001-2004 & $1996-2000$ & 2001-2004 & 1996-2000 & 2001-2004 \\
\hline & (1) & (2) & (3) & (4) & (5) & (6) & (7) \\
\hline$C F_{i, t}$ & $\begin{array}{c}0.185^{\star * *} \\
(0.017)\end{array}$ & $\begin{array}{l}0.245^{* * *} \\
(0.037)\end{array}$ & $\begin{array}{c}0.184^{* * *} \\
(0.027)\end{array}$ & $\begin{array}{c}0.221^{* * *} \\
(0.037)\end{array}$ & $\begin{array}{l}0.190^{* * *} \\
(0.027)\end{array}$ & $\begin{array}{c}0.245^{* * *} \\
(0.037)\end{array}$ & $\begin{array}{c}0.188^{* * *} \\
(0.027)\end{array}$ \\
\hline$\Delta y_{i, t}$ & $\begin{array}{c}0.015^{\star \star \star} \\
(0.003)\end{array}$ & $\begin{array}{c}0.020^{\star \star \star} \\
(0.007)\end{array}$ & $\begin{array}{l}0.011^{\star *} \\
(0.004)\end{array}$ & $\begin{array}{c}0.021^{\star * *} \\
(0.007)\end{array}$ & $\begin{array}{l}0.010^{* *} \\
(0.004)\end{array}$ & $\begin{array}{c}0.019^{\star \star \star} \\
(0.007)\end{array}$ & $\begin{array}{l}0.010^{* *} \\
(0.004)\end{array}$ \\
\hline$S_{i, t}$ & $\begin{array}{c}0.015^{\star * \star} \\
(0.004)\end{array}$ & $\begin{array}{l}0.028^{\star *} \\
(0.012)\end{array}$ & $\begin{array}{c}0.043^{* * *} \\
(0.008)\end{array}$ & $\begin{array}{c}0.042^{* * *} \\
(0.013)\end{array}$ & $\begin{array}{c}0.040^{\star * *} \\
(0.008)\end{array}$ & $\begin{array}{l}0.023^{*} \\
(0.012)\end{array}$ & $\begin{array}{c}0.040^{\star * *} \\
(0.008)\end{array}$ \\
\hline$I_{i, t}$ & 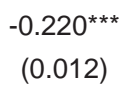 & $\begin{array}{c}-0.241^{* \star \star} \\
(0.022)\end{array}$ & $\begin{array}{c}-0.241^{* * \star} \\
(0.017)\end{array}$ & $\begin{array}{c}-0.244^{\star \star \star} \\
(0.022)\end{array}$ & $\begin{array}{c}-0.242^{\star \star *} \\
(0.017)\end{array}$ & $\begin{array}{c}-0.237^{\star \star *} \\
(0.022)\end{array}$ & $\begin{array}{c}-0.243^{* * *} \\
(0.017)\end{array}$ \\
\hline$\Delta N W C_{i, t}$ & $\begin{array}{c}-0.149^{\star \star *} \\
(0.006)\end{array}$ & $\begin{array}{c}-0.155^{\star \star *} \\
(0.012)\end{array}$ & $\begin{array}{c}-0.159^{* * *} \\
(0.009)\end{array}$ & $\begin{array}{c}-0.148^{\star * *} \\
(0.012)\end{array}$ & $\begin{array}{c}-0.161^{\star * *} \\
(0.009)\end{array}$ & $\begin{array}{c}-0.151^{\star * *} \\
(0.012)\end{array}$ & $\begin{array}{c}-0.161^{* * *} \\
(0.009)\end{array}$ \\
\hline$I S S_{i, t}$ & $\begin{array}{c}0.079^{* * *} \\
(0.004)\end{array}$ & $\begin{array}{c}0.103^{* * *} \\
(0.009)\end{array}$ & $\begin{array}{c}0.071^{* * *} \\
(0.006)\end{array}$ & $\begin{array}{c}0.095^{\star * *} \\
(0.009)\end{array}$ & $\begin{array}{c}0.071^{* * *} \\
(0.006)\end{array}$ & $\begin{array}{c}0.102^{* * *} \\
(0.009)\end{array}$ & $\begin{array}{c}0.071^{* * *} \\
(0.006)\end{array}$ \\
\hline$\Delta I N T_{i, t}$ & $\begin{array}{c}-0.130^{\star \star *} \\
(0.017)\end{array}$ & $\begin{array}{c}-0.252^{\star \star \star} \\
(0.048)\end{array}$ & $\begin{array}{c}-0.235^{\star * *} \\
(0.030)\end{array}$ & $\begin{array}{c}-0.241^{* \star *} \\
(0.047)\end{array}$ & $\begin{array}{c}-0.237^{\star * *} \\
(0.030)\end{array}$ & $\begin{array}{c}-0.243^{\star * *} \\
(0.048)\end{array}$ & $\begin{array}{c}-0.237^{\star \star *} \\
(0.030)\end{array}$ \\
\hline $\mathrm{R}$ & & & & $\begin{array}{c}-0.734^{* * *} \\
(0.129)\end{array}$ & $\begin{array}{l}-0.100 \\
(0.128)\end{array}$ & & \\
\hline 1999 & $\begin{array}{l}-0.002 \\
(0.002)\end{array}$ & & & & & & \\
\hline 2000 & $\begin{array}{c}-0.009^{\star \star *} \\
(0.002)\end{array}$ & & & & & & \\
\hline 2002 & $\begin{array}{l}-0.001 \\
(0.002)\end{array}$ & & & & & & \\
\hline 2003 & $\begin{array}{c}0.001 \\
(0.002)\end{array}$ & & & & & & \\
\hline Observations & 15,277 & 5,212 & 8,756 & 5,212 & 8,756 & 5,212 & 8,756 \\
\hline N. of firms & 4,771 & 2,606 & 3,333 & 2,606 & 3,333 & 2,606 & 3,333 \\
\hline R-squared & 0.184 & 0.212 & 0.201 & 0.224 & 0.199 & 0.211 & 0.199 \\
\hline Hansen p-val. & 0.289 & 0.393 & 0.134 & 0.282 & 0.0976 & 0.312 & 0.0912 \\
\hline
\end{tabular}

Notes: Regression of equation (1) as baseline estimation (columns 2 and 3). In column (1) we introduce year dummies, while in columns (4) and (5) we use the benchmark interest rate (R). In columns (6) and (7) we omit both $\Delta I N T_{i, t}$ and R. All regressions include two-digit industry dummies (CAE rev.2.1). Robust standard errors in parentheses. ${ }^{* \star *},{ }^{* \star}$, and ${ }^{*}$ denote statistical significance at the $.01, .05$, and .10 levels, respectively. Tables with confidence intervals and further test statistics available from the authors on request. Some of the statistics in this table were reported in Silva and Carreira (2011) 


\begin{tabular}{|c|c|c|c|c|c|c|c|c|c|c|c|}
\hline \multirow{3}{*}{$\begin{array}{l}\text { OPENESS } \\
\text { VARIABLES }\end{array}$} & \multirow{2}{*}{\begin{tabular}{|c|} 
NO \\
$1996-2004$ \\
\end{tabular}} & \multirow{2}{*}{\begin{tabular}{|c|} 
LOW \\
$1996-2000$ \\
\end{tabular}} & \multirow{2}{*}{\begin{tabular}{|c|} 
HIGH \\
$2001-2004$ \\
\end{tabular}} & \multicolumn{2}{|c|}{ NO } & \multicolumn{2}{|c|}{ YES } & \multicolumn{2}{|c|}{ LOW } & \multicolumn{2}{|c|}{$\mathrm{HIGH}$} \\
\hline & & & & 1996-2000 & 2001-2004 & 1996-2000 & 2001-2004 & $1996-2000$ & 2001-2004 & 1996-2000 & 2001-2004 \\
\hline & (1) & (2) & (3) & (4) & (5) & (6) & (7) & (8) & (9) & (10) & (11) \\
\hline$C F_{i, t}$ & $\begin{array}{l}0.269^{* * *} \\
(0.035)\end{array}$ & $\begin{array}{l}0.173^{\star \star *} \\
(0.030)\end{array}$ & $\begin{array}{l}0.107^{\star \star \star} \\
(0.027)\end{array}$ & $\begin{array}{l}0.284^{* \star \star} \\
(0.062)\end{array}$ & $\begin{array}{c}0.272^{* * *} \\
(0.056)\end{array}$ & $\begin{array}{l}0.208^{* * *} \\
(0.047)\end{array}$ & $\begin{array}{c}0.151^{\star \star *} \\
(0.032)\end{array}$ & $\begin{array}{l}0.167^{* *} \\
(0.068)\end{array}$ & $\begin{array}{l}0.221^{* \star *} \\
(0.049)\end{array}$ & $\begin{array}{l}0.240^{* \star *} \\
(0.065)\end{array}$ & $\begin{array}{l}0.110^{\star \star \star} \\
(0.043)\end{array}$ \\
\hline$\Delta y_{i, t}$ & $\begin{array}{l}0.018^{* * *} \\
(0.005)\end{array}$ & $\begin{array}{l}0.011^{* *} \\
(0.005)\end{array}$ & $\begin{array}{c}0.014^{* * *} \\
(0.005)\end{array}$ & $\begin{array}{l}0.031^{* *} \\
(0.013)\end{array}$ & $\begin{array}{l}0.012^{*} \\
(0.007)\end{array}$ & $\begin{array}{l}0.015^{*} \\
(0.008)\end{array}$ & $\begin{array}{l}0.008 \\
(0.005)\end{array}$ & $\begin{array}{l}0.022^{*} \\
(0.012)\end{array}$ & $\begin{array}{l}0.004 \\
(0.008)\end{array}$ & $\begin{array}{c}0.009 \\
(0.011)\end{array}$ & $\begin{array}{l}0.013^{*} \\
(0.007)\end{array}$ \\
\hline$S_{i, t}$ & $\begin{array}{l}0.018^{* *} \\
(0.008)\end{array}$ & $\begin{array}{l}0.018^{* * *} \\
(0.006)\end{array}$ & $\begin{array}{c}0.025^{\star \star *} \\
(0.007)\end{array}$ & $\begin{array}{c}0.025 \\
(0.024)\end{array}$ & $\begin{array}{l}0.032^{* *} \\
(0.014)\end{array}$ & $\begin{array}{l}0.026^{*} \\
(0.015)\end{array}$ & $\begin{array}{c}0.059^{* * *} \\
(0.009)\end{array}$ & $\begin{array}{l}-0.010 \\
(0.022)\end{array}$ & $\begin{array}{l}0.055^{* \star *} \\
(0.014)\end{array}$ & $\begin{array}{l}0.048^{* *} \\
(0.021)\end{array}$ & $\begin{array}{l}0.070^{* * *} \\
(0.012)\end{array}$ \\
\hline$I_{i, t}$ & $\begin{array}{l}-0.252^{* \star *} \\
(0.023)\end{array}$ & $\begin{array}{c}-0.200^{* * *} \\
(0.022)\end{array}$ & $\begin{array}{c}-0.222^{* * *} \\
(0.019)\end{array}$ & $\begin{array}{c}-0.263^{* * *} \\
(0.042)\end{array}$ & $\begin{array}{c}-0.266^{* * *} \\
(0.032)\end{array}$ & $\begin{array}{c}-0.224^{\star \star *} \\
(0.029)\end{array}$ & $\begin{array}{c}-0.243^{\star * *} \\
(0.020)\end{array}$ & $\begin{array}{l}-0.161^{\star \star *} \\
(0.044)\end{array}$ & $\begin{array}{c}-0.234^{\star * *} \\
(0.036)\end{array}$ & $\begin{array}{c}-0.251^{* * *} \\
(0.040)\end{array}$ & $\begin{array}{c}-0.260^{* * *} \\
(0.027)\end{array}$ \\
\hline$\Delta N W C_{i, t}$ & $\begin{array}{l}-0.166^{* * *} \\
(0.012)\end{array}$ & $\begin{array}{c}-0.134^{* * *} \\
(0.011)\end{array}$ & $\begin{array}{c}-0.161^{* * *} \\
(0.011)\end{array}$ & $\begin{array}{c}-0.168^{* * *} \\
(0.025)\end{array}$ & $\begin{array}{c}-0.177^{* * *} \\
(0.018)\end{array}$ & $\begin{array}{c}-0.148^{* * *} \\
(0.014)\end{array}$ & $\begin{array}{c}-0.163^{* * *} \\
(0.011)\end{array}$ & $\begin{array}{l}-0.137^{\star * *} \\
(0.022)\end{array}$ & $\begin{array}{c}-0.150^{* * *} \\
(0.018)\end{array}$ & $\begin{array}{c}-0.166^{* \star *} \\
(0.019)\end{array}$ & $\begin{array}{c}-0.182^{* * *} \\
(0.017)\end{array}$ \\
\hline$I S S_{i, t}$ & $\begin{array}{l}0.080^{\star * *} \\
(0.008)\end{array}$ & $\begin{array}{c}0.078^{* * *} \\
(0.008)\end{array}$ & $\begin{array}{c}0.076^{* * *} \\
(0.008)\end{array}$ & $\begin{array}{l}0.108^{* * *} \\
(0.018)\end{array}$ & $\begin{array}{c}0.069^{* * *} \\
(0.012)\end{array}$ & $\begin{array}{c}0.098^{* * *} \\
(0.011)\end{array}$ & $\begin{array}{c}0.075^{* * *} \\
(0.008)\end{array}$ & $\begin{array}{l}0.107^{\star \star *} \\
(0.015)\end{array}$ & $\begin{array}{c}0.076^{\star \star *} \\
(0.012)\end{array}$ & $\begin{array}{l}0.092^{* * *} \\
(0.016)\end{array}$ & $\begin{array}{c}0.067^{\star * *} \\
(0.011)\end{array}$ \\
\hline$\Delta I N T_{i, t}$ & $\begin{array}{l}-0.484^{* * *} \\
(0.177)\end{array}$ & $\begin{array}{l}-0.081 \\
(0.144)\end{array}$ & $\begin{array}{c}-0.552^{* * *} \\
(0.168)\end{array}$ & $\begin{array}{l}-0.082 \\
(0.306)\end{array}$ & $\begin{array}{c}-0.685^{* *} \\
(0.285)\end{array}$ & $\begin{array}{l}-0.301 \\
(0.202)\end{array}$ & $\begin{array}{l}-0.196 \\
(0.156)\end{array}$ & $\begin{array}{l}0.186 \\
(0.266)\end{array}$ & $\begin{array}{c}0.071 \\
(0.218)\end{array}$ & $\begin{array}{l}-0.704^{* *} \\
(0.312)\end{array}$ & $\begin{array}{l}-0.492^{* *} \\
(0.229)\end{array}$ \\
\hline FinI $_{i, t}$ & $\begin{array}{l}-0.198^{* * *} \\
(0.046)\end{array}$ & $\begin{array}{c}-0.116^{\star \star *} \\
(0.030)\end{array}$ & $\begin{array}{c}-0.107^{\star * *} \\
(0.030)\end{array}$ & $\begin{array}{l}-0.404^{* * *} \\
(0.100)\end{array}$ & $\begin{array}{c}-0.286^{* * *} \\
(0.083)\end{array}$ & $\begin{array}{c}-0.246^{* * *} \\
(0.055)\end{array}$ & $\begin{array}{c}-0.242^{* \star *} \\
(0.033)\end{array}$ & $\begin{array}{l}-0.215^{* * *} \\
(0.077)\end{array}$ & $\begin{array}{c}-0.264^{* * *} \\
(0.062)\end{array}$ & $\begin{array}{c}-0.305^{\star * *} \\
(0.081)\end{array}$ & $\begin{array}{c}-0.221^{* * *} \\
(0.037)\end{array}$ \\
\hline Observations & 4,299 & 4,163 & 5,173 & 1,274 & 2,497 & 3,400 & 5,502 & 1,282 & 2,340 & 1,802 & 2,789 \\
\hline N. of firms & 1,537 & 1,462 & 1,632 & 637 & 1,008 & 1,700 & 2,160 & 641 & 960 & 901 & 1,093 \\
\hline R-squared & 0.221 & 0.180 & 0.180 & 0.265 & 0.235 & 0.199 & 0.211 & 0.202 & 0.207 & 0.212 & 0.236 \\
\hline Hansen p-val. & 0.251 & 0.200 & 0.729 & 0.268 & 0.182 & 0.930 & 0.514 & 0.986 & 0.540 & 0.621 & 0.477 \\
\hline
\end{tabular}

Notes: Regression of equation (1). Firms' openness score definition in Appendix. All regressions include two-digit industry dummies (CAE rev.2.1). Robust standard errors in parentheses. ${ }^{* \star *},{ }^{* *}$, and ${ }^{*}$ denote statistical significance at the $.01, .05$, and .10 levels, respectively. Tables with confidence intervals and further test statistics available from the authors on request. Some of the statistics in this table were reported in Silva and Carreira (2011) 


\subsection{Exporting and importing}

As expected, Table 3 shows that there might be an inverse relationship between the degree of openness to foreign markets and financial constraints since, for the whole period, the higher the openness, the lower is the CCFS (columns 1-3 report the CCFS estimates that are all statistically different). This result may arise either because more open firms may have better access to foreign finance or only unconstrained firms are able to exploit foreign markets.

Interestingly, when we split the sample by the two major periods, we find a reduction in constraints for open firms (columns 6 and 7), while the level of financial constraints of closed firms remains mostly unchanged (columns 4 and 5). However, depending on the degree of openness, firms' financial constraints were either reduced (columns 10 and 11) or, if not equal (estimates in columns 8 and 9 are not statistically different), were amplified. This is a puzzling result since we would expect, a priori, that even though the reduction in constraints should be larger for highly open firms, firms with lower levels of openness should also exhibit a reduction in constraints, given that monetary integration should benefit mostly those firms that also have businesses overseas (through exchange rate stability and access to both foreign banks and financial markets). Additional differences arise between firms with low and high levels of openness with respect to the impacts of sales growth, investment and variation of interest paid. We also tested the inclusion of real GDP growth or unemployment, in order to capture possible influences of the economic cycle, nevertheless the results remain very similar. Results remain unchanged if we additionally control for the benchmark interest rate, number of employees or age or even if, instead of degree of openness-EU, we use total degree of openness ${ }^{19}$.

These results indicate that while highly open firms benefited the most with the integration, closed firms experienced no changes with respect to constraints and, most interestingly, slightly open firms faced, if not the same, higher constraints in the second period. This odd result arises for firms that have very small degrees of openness - smaller than $0.5 \%$, while for firms between $0.5 \%$ and $1 \%$ the results are as previously hypothesised 20 . This might, however, be associated with larger competition for funds in the integrated markets, since firms with low degrees of openness might not be as visible abroad as they would be in the domestic market, while at the same time, losing their advantage on the domestic market, where lenders will then opt to finance domestic or even foreign firms with better prospects. In fact, if we compare the level of constraints of these firms with those of closed firms, the difference in CCFS estimates is larger for the initial period than for the second period. One could argue that lenders would no longer distinguish between slightly open and closed firms.

If instead we look at firm export and import activity separately, we see that firms with higher export or import intensities are less financially constrained, as expected, even though the pattern is clearer for the case of exports - while for exports (Table 4, columns 1-3) all estimates are statistically different, for the case of imports (Table 5, columns 1-3), high intensity estimates are not statistically different from those of lower intensity. However, when we compare the levels of constraints before and after monetary integration, distinct patterns arise. While no significant differences between periods are found for firms that either imported or not (Table 5, columns 47), firms that either exported or not (Table 4, columns 4-7) seem to have experienced a slight reduction in constraints with integration (a formal Wald test only rejects that the coefficients are statistically equal at the $90 \%$ level). Nevertheless, the levels of constraints for non-exporting firms in the second period is much larger than those of exporting firms in the first period (Table 4, columns 5 and 6 , respectively) ${ }^{21}$.

If we further distinguish between low and high levels of export and import intensities, we find a clear contrast between these firms. Whereas for high export intensity firms, financial constraints 
levels remain unchanged at low levels (estimates in columns 10 and 11 of Table 4 are not statistically different), high intensity importers experienced a clear reduction in constraints (Table 5 , columns 10 and 11). These results suggest that firms that rely mostly on imports accrued larger benefits from integration than did export driven firms. This may arise because the former saw their credit conditions improved overseas, while the latter already benefited from a privileged position before integration, corroborated by the CCFS estimates for the first period (Table 5, column 10). Conversely, while there is a clear increase in financial constraints for firms with lower import intensities (Table 5, columns 8 and 9), the level of constraints for firms with low export intensity, if not lower, remains practically unchanged in the second period (Table 4, columns 8 and 9 report CCFS estimates that are not statistically different). This result clarifies the higher CCFS, after integration, found for firms with lower degree of openness, provided it is due to an higher contribution of importing firms rather than exporting ones.

\begin{tabular}{|c|c|c|c|c|c|c|c|c|c|c|c|}
\hline \multirow{3}{*}{$\begin{array}{c}\text { EXPORT } \\
\text { VARIABLES }\end{array}$} & NO & LOW & HIGH & \multicolumn{2}{|c|}{ NO } & \multicolumn{2}{|c|}{ YES } & \multicolumn{2}{|c|}{ LOW } & \multicolumn{2}{|c|}{ HIGH } \\
\hline & $1996-2004$ & 1996-2000 & 2001-2004 & 1996-2000 & $2001-2004$ & $1996-2000$ & 2001-2004 & 1996-2000 & 2001-2004 & $1996-2000$ & 2001-2004 \\
\hline & (1) & (2) & (3) & (4) & (5) & (6) & (7) & (8) & (9) & (10) & (11) \\
\hline$C F_{i, t}$ & $\begin{array}{l}0.271^{\star \star *} \\
(0.027)\end{array}$ & $\begin{array}{c}0.135^{* * *} \\
(0.036)\end{array}$ & $\begin{array}{l}0.062^{* *} \\
(0.027)\end{array}$ & $\begin{array}{c}0.313^{* * *} \\
(0.059)\end{array}$ & $\begin{array}{c}0.269^{* * *} \\
(0.041)\end{array}$ & $\begin{array}{c}0.151^{* * *} \\
(0.047)\end{array}$ & $\begin{array}{c}0.099^{* * *} \\
(0.035)\end{array}$ & $\begin{array}{l}0.186^{*} \\
(0.106)\end{array}$ & $\begin{array}{l}0.119^{* *} \\
(0.056)\end{array}$ & $\begin{array}{l}0.130^{* *} \\
(0.051)\end{array}$ & $\begin{array}{l}0.098^{* *} \\
(0.045)\end{array}$ \\
\hline$\Delta y_{i, t}$ & $\begin{array}{l}0.014^{* * *} \\
(0.004)\end{array}$ & $\begin{array}{l}0.010 \\
(0.006)\end{array}$ & $\begin{array}{c}0.015^{* * *} \\
(0.005)\end{array}$ & $\begin{array}{l}0.030^{* \star *} \\
(0.011)\end{array}$ & $\begin{array}{c}0.009 \\
(0.006)\end{array}$ & $\begin{array}{l}0.017^{\star *} \\
(0.008)\end{array}$ & $\begin{array}{c}0.015^{\star * *} \\
(0.006)\end{array}$ & $\begin{array}{l}0.030^{* *} \\
(0.014)\end{array}$ & $\begin{array}{c}0.005 \\
(0.008)\end{array}$ & $\begin{array}{c}0.006 \\
(0.010)\end{array}$ & $\begin{array}{c}0.021^{* * *} \\
(0.008)\end{array}$ \\
\hline$S_{i, t}$ & $\begin{array}{l}0.016^{* * *} \\
(0.006)\end{array}$ & $\begin{array}{l}0.021^{* *} \\
(0.008)\end{array}$ & $\begin{array}{c}0.019^{* * *} \\
(0.007)\end{array}$ & $\begin{array}{c}0.013 \\
(0.019)\end{array}$ & $\begin{array}{c}0.043^{* * *} \\
(0.012)\end{array}$ & $\begin{array}{l}0.040^{* *} \\
(0.016)\end{array}$ & $\begin{array}{c}0.042^{* * *} \\
(0.011)\end{array}$ & $\begin{array}{l}0.077^{\star \star *} \\
(0.024)\end{array}$ & $\begin{array}{c}0.014 \\
(0.016)\end{array}$ & $\begin{array}{l}0.044^{* *} \\
(0.021)\end{array}$ & $\begin{array}{c}0.052^{* * *} \\
(0.015)\end{array}$ \\
\hline$I_{i, t}$ & $\begin{array}{l}-0.253^{* * *} \\
(0.018)\end{array}$ & $\begin{array}{c}-0.210^{* * *} \\
(0.024)\end{array}$ & $\begin{array}{c}-0.174^{* * *} \\
(0.020)\end{array}$ & $\begin{array}{l}-0.253^{* * *} \\
(0.036)\end{array}$ & $\begin{array}{c}-0.271^{* * *} \\
(0.026)\end{array}$ & $\begin{array}{c}-0.235^{* * *} \\
(0.031)\end{array}$ & $\begin{array}{c}-0.203^{* * *} \\
(0.021)\end{array}$ & $\begin{array}{c}-0.275^{* * *} \\
(0.048)\end{array}$ & $\begin{array}{c}-0.211^{* * *} \\
(0.032)\end{array}$ & $\begin{array}{c}-0.212^{* \star *} \\
(0.039)\end{array}$ & $\begin{array}{c}-0.200^{* * *} \\
(0.028)\end{array}$ \\
\hline$\Delta N W C_{i, t}$ & $\begin{array}{l}-0.158^{* * *} \\
(0.010)\end{array}$ & $\begin{array}{c}-0.155^{* * *} \\
(0.013)\end{array}$ & $\begin{array}{c}-0.142^{* * *} \\
(0.011)\end{array}$ & $\begin{array}{c}-0.158^{* \star *} \\
(0.020)\end{array}$ & $\begin{array}{c}-0.167^{* * *} \\
(0.014)\end{array}$ & $\begin{array}{c}-0.159^{* * *} \\
(0.015)\end{array}$ & $\begin{array}{c}-0.156^{* * *} \\
(0.013)\end{array}$ & $\begin{array}{c}-0.164^{* \star *} \\
(0.026)\end{array}$ & $\begin{array}{c}-0.170^{* \star *} \\
(0.020)\end{array}$ & $\begin{array}{c}-0.156^{\star \star *} \\
(0.019)\end{array}$ & $\begin{array}{c}-0.156^{* \star *} \\
(0.017)\end{array}$ \\
\hline$I S S_{i, t}$ & $\begin{array}{l}0.086^{* * *} \\
(0.007)\end{array}$ & $\begin{array}{c}0.087^{\star * *} \\
(0.008)\end{array}$ & $\begin{array}{l}0.063^{* * *} \\
(0.008)\end{array}$ & $\begin{array}{l}0.111^{* * *} \\
(0.015)\end{array}$ & $\begin{array}{l}0.079^{* * *} \\
(0.009)\end{array}$ & $\begin{array}{l}0.100^{* * *} \\
(0.012)\end{array}$ & $\begin{array}{c}0.064^{* * *} \\
(0.008)\end{array}$ & $\begin{array}{l}0.109^{* * *} \\
(0.017)\end{array}$ & $\begin{array}{l}0.081^{* * *} \\
(0.012)\end{array}$ & $\begin{array}{l}0.087^{\star \star *} \\
(0.016)\end{array}$ & $\begin{array}{c}0.047^{* \star *} \\
(0.011)\end{array}$ \\
\hline$\Delta I N T_{i, t}$ & $\begin{array}{l}-0.420^{\star * *} \\
(0.139)\end{array}$ & $\begin{array}{l}-0.385^{* *} \\
(0.186)\end{array}$ & $\begin{array}{l}-0.359^{* *} \\
(0.169)\end{array}$ & $\begin{array}{l}-0.039 \\
(0.241)\end{array}$ & $\begin{array}{l}-0.553^{* *} \\
(0.223)\end{array}$ & $\begin{array}{l}-0.381^{*} \\
(0.222)\end{array}$ & $\begin{array}{c}-0.449^{* *} \\
(0.177)\end{array}$ & $\begin{array}{l}-0.748^{* *} \\
(0.352)\end{array}$ & $\begin{array}{l}-0.373 \\
(0.254)\end{array}$ & $\begin{array}{l}-0.258 \\
(0.292)\end{array}$ & $\begin{array}{l}-0.333 \\
(0.235)\end{array}$ \\
\hline FinI $_{i, t}$ & $\begin{array}{l}-0.162^{* * *} \\
(0.032)\end{array}$ & $\begin{array}{c}-0.161^{* * *} \\
(0.035)\end{array}$ & $\begin{array}{l}-0.079^{* *} \\
(0.032)\end{array}$ & $\begin{array}{l}-0.241^{* * *} \\
(0.075)\end{array}$ & $\begin{array}{c}-0.321^{* * *} \\
(0.061)\end{array}$ & $\begin{array}{c}-0.322^{* * *} \\
(0.071)\end{array}$ & $\begin{array}{c}-0.190^{* * *} \\
(0.030)\end{array}$ & $\begin{array}{c}-0.369^{* * *} \\
(0.088)\end{array}$ & $\begin{array}{c}-0.207^{* * *} \\
(0.049)\end{array}$ & $\begin{array}{c}-0.294^{* \star *} \\
(0.101)\end{array}$ & $\begin{array}{c}-0.181^{* * *} \\
(0.042)\end{array}$ \\
\hline Observations & 6,475 & 3,293 & 4,299 & 1,984 & 3,804 & 2,762 & 4,333 & 1,022 & 1,833 & 1,580 & 2,280 \\
\hline N. of firms & 2,210 & 1,144 & 1,333 & 992 & 1,500 & 1,381 & 1,689 & 511 & 742 & 790 & 884 \\
\hline R-squared & 0.212 & 0.210 & 0.154 & 0.241 & 0.231 & 0.225 & 0.194 & 0.282 & 0.218 & 0.202 & 0.188 \\
\hline Hansen p-val. & 0.228 & 0.509 & 0.728 & 0.173 & 0.665 & 0.875 & 0.633 & 0.791 & 0.237 & 0.782 & 0.819 \\
\hline
\end{tabular}

Notes: Regression of equation (1). Firms' export intensity scores definition in Appendix. All regressions include two-digit industry dummies (CAE rev.2.1). Robust standard errors in parentheses. ${ }^{* * *}$, ${ }^{* *}$, and ${ }^{*}$ denote statistical significance at the $.01, .05$, and .10 levels, respectively. Tables with confidence intervals and further test statistics available from the authors on request. 
TABLE 5 - CCFS estimation by import intensity-EU

\begin{tabular}{|c|c|c|c|c|c|c|c|c|c|c|c|}
\hline \multirow{3}{*}{$\begin{array}{c}\text { IMPORT } \\
\text { VARIABLES }\end{array}$} & NO & LOW & HIGH & \multicolumn{2}{|c|}{ NO } & \multicolumn{2}{|c|}{ YES } & \multicolumn{2}{|c|}{ LOW } & \multicolumn{2}{|c|}{ HIGH } \\
\hline & 1996-2004 & $1996-2000$ & 2001-2004 & \begin{tabular}{|l|l|}
4 & $1996-2000$ \\
\end{tabular} & \multirow{2}{*}{\begin{tabular}{|c|}
$2001-2004$ \\
$(5)$ \\
\end{tabular}} & \multirow{2}{*}{\begin{tabular}{|c|}
$1996-2000$ \\
$(6)$ \\
\end{tabular}} & \multirow{2}{*}{\begin{tabular}{|c|}
$2001-2004$ \\
$(7)$
\end{tabular}} & \multicolumn{2}{|c|}{ 1996-2000 2001-2004 } & \multicolumn{2}{|c|}{\begin{tabular}{|l|l|}
$1996-2000$ & $2001-2004$ \\
\end{tabular}} \\
\hline & (1) & (2) & (3) & (4) & & & & (8) & (9) & (10) & (11) \\
\hline \multirow{2}{*}{$C F_{i, t}$} & $0.259^{* \star \star}$ & $0.142^{\star \star \star}$ & $0.118^{* \star \star}$ & $0.278^{\star \star \star}$ & $0.271^{* \star \star}$ & $0.192^{* \star *}$ & $0.168^{\star \star \star}$ & 0.078 & $0.211^{\star \star \star}$ & $0.307^{* \star \star}$ & $0.126^{* * \star}$ \\
\hline & $(0.033)$ & $(0.032)$ & $(0.030)$ & $(0.061)$ & $(0.053)$ & $(0.051)$ & $(0.034)$ & $(0.066)$ & $(0.053)$ & $(0.092)$ & $(0.047)$ \\
\hline \multirow[t]{2}{*}{$\Delta y_{i, t}$} & $0.017^{* * *}$ & $0.014^{* *}$ & 0.005 & $0.033^{* * *}$ & 0.010 & $0.016^{*}$ & 0.008 & 0.017 & 0.008 & 0.009 & 0.003 \\
\hline & $(0.005)$ & $(0.006)$ & $(0.005)$ & $(0.012)$ & $(0.007)$ & $(0.009)$ & $(0.006)$ & $(0.012)$ & $(0.009)$ & $(0.014)$ & $(0.008)$ \\
\hline \multirow[t]{2}{*}{$S_{i, t}$} & $0.017^{* *}$ & $0.018^{\star \star \star}$ & $0.020^{* * *}$ & 0.017 & $0.032^{* *}$ & $0.032^{* *}$ & $0.061^{* * *}$ & 0.009 & $0.054^{* * *}$ & $0.071^{* * *}$ & $0.052^{* * *}$ \\
\hline & $(0.007)$ & $(0.007)$ & $(0.007)$ & $(0.023)$ & $(0.013)$ & $(0.016)$ & $(0.010)$ & $(0.023)$ & $(0.013)$ & $(0.024)$ & $(0.015)$ \\
\hline \multirow[t]{2}{*}{$I_{i, t}$} & $-0.248^{* * *}$ & $-0.176^{* * *}$ & $-0.253^{* \star \star}$ & $-0.238^{\star * *}$ & $-0.264^{* * *}$ & $-0.245^{* * *}$ & $*-0.242^{* * *}$ & $-0.135^{\star * *}$ & $-0.251^{* * *}$ & $-0.280^{* * *}$ & $-0.263^{* * *}$ \\
\hline & $(0.022)$ & $(0.024)$ & $(0.019)$ & $(0.041)$ & $(0.030)$ & $(0.032)$ & $(0.022)$ & $(0.049)$ & $(0.041)$ & $(0.040)$ & $(0.028)$ \\
\hline \multirow[t]{2}{*}{$\Delta N W C_{i, t}$} & $-0.159^{* * *}$ & $-0.132^{* * *}$ & $-0.167^{\star \star \star}$ & $-0.165^{\star * *}$ & $-0.172^{* * *}$ & $-0.150^{* * *}$ & $-0.168^{* * *}$ & $-0.145^{\star * *}$ & $-0.143^{* \star *}$ & $-0.147^{\star * *}$ & $-0.192^{* * *}$ \\
\hline & $(0.011)$ & $(0.013)$ & $(0.012)$ & $(0.023)$ & $(0.016)$ & $(0.014)$ & $(0.013)$ & $(0.023)$ & $(0.020)$ & $(0.021)$ & $(0.018)$ \\
\hline \multirow[t]{2}{*}{$I S S_{i, t}$} & $0.077^{\star \star \star}$ & $0.066^{* * *}$ & $0.091^{* * *}$ & $0.103^{* * *}$ & $0.067^{* \star *}$ & $0.095^{* * *}$ & $0.075^{* \star *}$ & $0.098^{\star \star *}$ & $0.067^{* \star *}$ & $0.095^{* \star *}$ & $0.095^{* * *}$ \\
\hline & $(0.008)$ & $(0.008)$ & $(0.008)$ & $(0.016)$ & $(0.011)$ & $(0.012)$ & $(0.009)$ & $(0.020)$ & $(0.013)$ & $(0.018)$ & $(0.012)$ \\
\hline \multirow[t]{2}{*}{$\Delta I N T_{i, t}$} & $-0.483^{* * *}$ & -0.166 & -0.267 & -0.118 & $-0.623^{* *}$ & $-0.369^{*}$ & -0.273 & -0.044 & -0.041 & $-0.663^{*}$ & -0.216 \\
\hline & $(0.165)$ & $(0.151)$ & $(0.177)$ & $(0.290)$ & $(0.266)$ & $(0.219)$ & $(0.167)$ & $(0.254)$ & $(0.238)$ & $(0.382)$ & $(0.257)$ \\
\hline \multirow[t]{2}{*}{$\operatorname{FinI}_{i, t}$} & $-0.188^{* \star *}$ & $-0.102^{* * *}$ & $-0.117^{\star \star \star}$ & $-0.305^{* \star *}$ & $-0.272^{* \star *}$ & $-0.267^{* \star *}$ & ${ }^{*}-0.232^{* \star *}$ & $-0.172^{* * *}$ & $-0.257^{* * *}$ & $-0.379^{* * *}$ & $-0.204^{* * *}$ \\
\hline & $(0.042)$ & $(0.031)$ & $(0.031)$ & $(0.104)$ & $(0.070)$ & $(0.058)$ & $(0.035)$ & $(0.066)$ & $(0.066)$ & $(0.084)$ & $(0.038)$ \\
\hline Observations & 4,925 & & & 1,426 & 2,845 & 3,076 & 4,977 & 1,142 & 2,109 & 1,532 & 2,461 \\
\hline of firms & 1,782 & 1,374 & 1,523 & 713 & 1,156 & 1,538 & 1,967 & 571 & 871 & 766 & 984 \\
\hline R-squared & 0.212 & 0.155 & 0.192 & 0.250 & 0.225 & 0.194 & 0.211 & 0.182 & 0.193 & 0.240 & 0.231 \\
\hline Hansen p-val. & 0.341 & 0.241 & 0.857 & 0.337 & 0.209 & 0.999 & 0.531 & 0.632 & 0.988 & 0.479 & 0.126 \\
\hline
\end{tabular}

Notes: Regression of equation (1). Firms' import intensity scores definition in Appendix. All regressions include two-digit industry dummies (CAE rev.2.1). Robust standard errors in parentheses. ${ }^{* * *}$, ${ }^{\star *}$, and * denote statistical significance at the $.01, .05$, and .10 levels, respectively. Tables with confidence intervals and further test statistics available from the authors on request.

In order to verify if firms' constraints were actually reduced with shifting, there is no longer a point in analysing firm openness, since if a firm starts importing, even though there might be a constraints alleviating effect due to relationships established abroad, the opposite effect might be larger due to a possible necessity of importing goods (either machinery or raw materials) that boosts the demand for cash (this pattern is clear from the comparison of columns 5 and 6 in Table 6). However, if we look at firms that started exporting, it is clear that the self-selection effect (financial constraints barrier) is not as large as the benefits accruing from access to better finance either abroad or at home, as we can see from the comparison of the estimates from columns 4 and 5 (CCFS coefficients dropped from 0.265 to 0.145 and are statistically different). If instead estimates on CCFS before and after starting to export would be similar, then this would suggest that less constrained firms would self-select into exporting ${ }^{22}$. These results are the periods before shifting to those after shifting, which results from the estimator used, that requires at least 3 
confirmed if, instead of splitting the sample, we interact cash-flow with a binary indicator for the shifting status - before and after shifting (Table A1 in appendix). Nevertheless, even after starting to export, these firms still face significant constraints as they save, on average, 15 cents out of each extra euro of cash-flow. Finally, the fact that, on average, firms before starting to export present high CCFS (they save 27 cents out of each euro of extra cash-flow), casts serious doubts on the hypothesis that only unconstrained firms self-select into exporting activity.

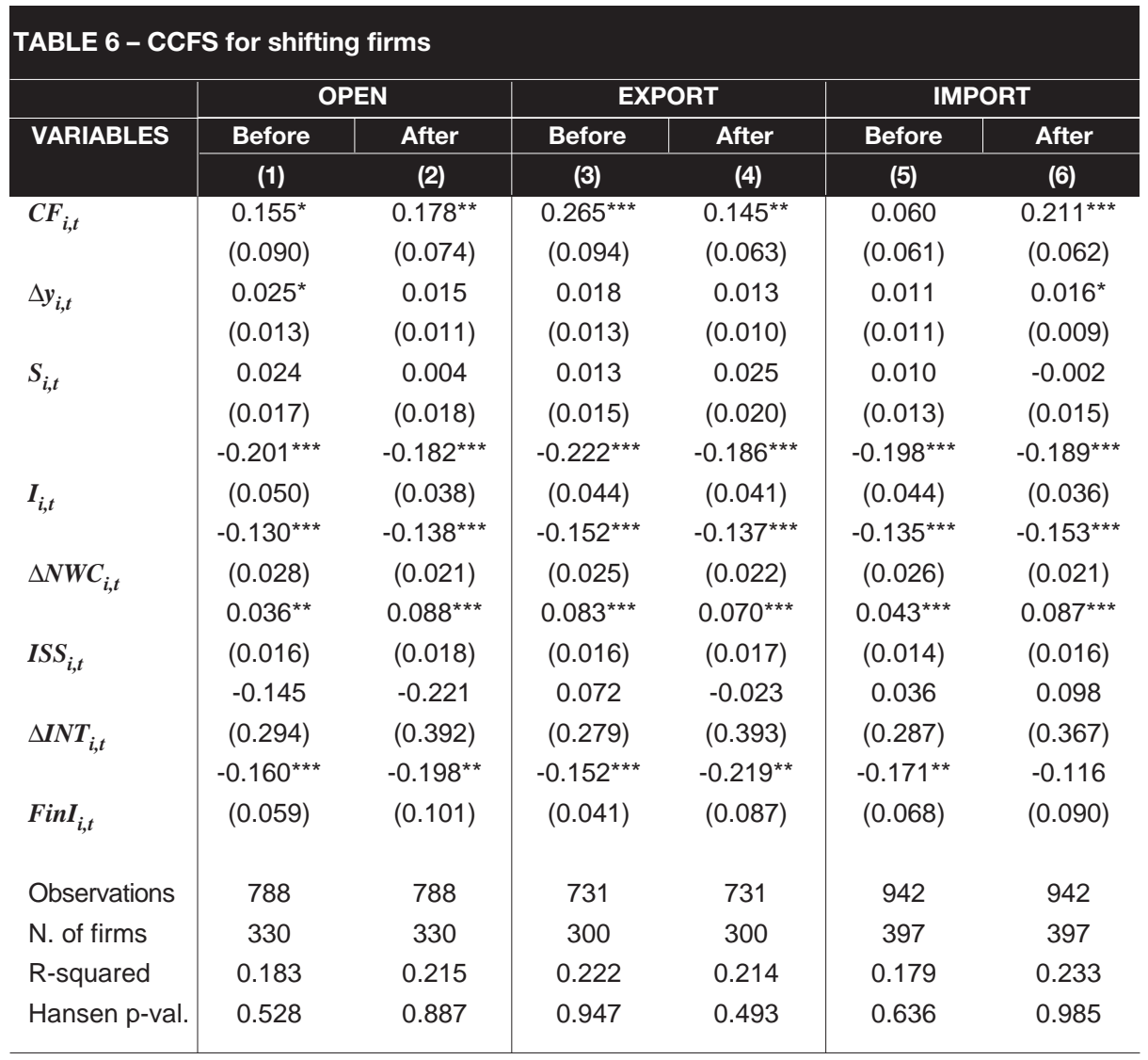

Notes: Regression of equation (1) for groups of firms that moved from closed to open, started exporting those that started importing. All regressions include two-digit industry dummies (CAE rev.2.1). Robust standard errors in parentheses. ${ }^{* * *},{ }^{* *}$, and ${ }^{*}$ denote statistical significance at the $.01, .05$, and .10 levels, respectively. Tables with confidence intervals and further test statistics available from the authors upon request. 
In this paper we investigate the extent to which the European monetary integration has influenced firms' financial distress, as well as the impact of financial constraints upon firms with different exporting and importing activities.

Our main findings suggest that firms with higher degrees of openness and particularly those with higher export intensities face much lower financial constraints. Additionally, while we cast some doubts on the argument that only unconstrained firms self-select into exporting activity, we show that firms face lower constraints once they start exporting.

Furthermore, we find that financial and monetary integration has helped in reducing firms' financial constraints. Only for low intensity importers did the level of constraints increase. While this process benefited mostly firms that were highly open, there was no substantial effect upon firms that relied solely on their domestic market. Overall, these results show that these integration processes alleviate firms' financial constraints by easing their access to finance abroad and reducing the price of money in domestic markets.

Further research should aim at extending this analysis to a wider time span, particularly covering the recent financial crisis, as well as at comparing the level of constraints for exporting firms across different economies. 
Acharya, V.; Almeida, H. ; Campello, M. (2007) Is cash negative debt? A hedging perspective on corporate financial policies, Journal of Financial Intermediation, 16, 515-554.

Almeida, H. ; Campello, M.; Weisbach, M.S. (2004) The cash flow sensitivity of cash, Journal of Finance, 59, 1777-1804.

Almeida, H.; Campello, M.; Weisbach, M. (2011) Corporate financial and investment policies when future financing is not frictionless, Journal of Corporate Finance, 17, 675-693.

Alti, A. (2003) How sensitive is investment to cash flow when financing is frictionless? Journal of Finance, 58, 707-722.

Amiti, M.; Weinstein, D. (2009) Exports and financial shocks, NBER Working Paper No. 15556.

Bekaert, G.; Hodrick, R. (2008) International Financial Management, New Jersey, Prentice Hall.

Bellone, F.; Musso, P.; Nesta, L.; Schiavo, S. (2010) Financial constraints and firm export behavior, The World Economy, 33, 347-373.

Berman, N.; Hericourt, J. (2010) Financial factors and the margins of trade: Evidence from crosscountry firm-level data, Journal of Development Economics, 93, 206-217.

Bond, S.; Elston, J.; Mairesse, J.; Mulkay, B. (2003) Financial factors and investment in Belgium, France, Germany, and the United Kingdom: A comparison using company panel data, Review of Economics and Statistics, 85, 153-165.

Bridges, S.; Guariglia, A. (2008) Financial constraints, global engagement, and firm survival in the United Kingdom: Evidence from micro data, Scottish Journal of Political Economy, 55, 444$-64$.

Broll, U.; Wahl, J. (2011) Liquidity constrained exporters and trade, Economics Letters, 111, 26-29.

Budina, N.; Garretsen, H.; de Jong, E. (2000) Liquidity constraints and investment in transition economies: The case of Bulgaria, Economics of Transition, 8, 453-475.

Cabral, L.; Mata, J. (2003) On the evolution of the firm size distribution: Facts and theory, American Economic Review, 93, 1075-1090.

Carreira, C.; Silva, F. (2010) No deep pockets: Some stylized results on firms' financial constraints, Journal of Economic Surveys, 24, 731-753.

Chaney, T. (2005), Liquidity constrained exporters, University of Chicago, Mimeo.

Chor, D.; Manova, K. (2011) Off the cliff and back? Credit conditions and international trade during the global financial crisis, Journal of International Economics (forthcoming) DOI: 10.1016/j.jinteco.2011.04.001

Fazzari, S.M.; Hubbard, R.G.; Petersen, B.C. (1988) Financing constraints and corporate investment, Brookings Papers on Economic Activity, 141-195.

Forlani, E. (2010) Liquidity constraints and firm's export activity, Centro Studi Luca d'Agliano Development Studies Working Paper No. 291

Ganesh-Kumar, A.; Sen, K.; Vaidya, R. (2001) Outward orientation, investment and finance constraints: A study of Indian firms, Journal of Development Studies, 37, 133-149.

Gorg, H.; Spaliara, M. (2009) Financial health, exports, and firm survival: A comparison of British and French firms, Working Paper 7532, CEPR.

Greenaway, D.; Guariglia, A.; Kneller, R. (2007) Financial factors and exporting decisions, Journal of International Economics, 73, 377-395. 
Hahn, F. (2010) Corporate reserves - Do they hurt economic growth? Some empirical evidence from OECD countries, Economics Letters, 109, 91-93

Harhoff, D. (1998) Are there financing constraints for R\&D and investment in German manufacturing firms, Annales d'Economie et de Statistique, 49/50, 421-456.

Hayashi, F. (1981) Tobin's marginal q and average q: A neoclassical interpretation, Econometrica, 50, 213-24.

Hernández-Cánovas, G.; Martínez-Solano, P. (2010) Relationship lending and SME financing in the continental European bank-based system, Small Business Economics, 34, 465-482.

Hubbard R. G. (1998) Capital-market imperfections and investment, Journal of Economic Literature, 36, 193-225.

Kaplan, S.N.; Zingales, L. (1997) Do investment-cash flow sensitivities provide useful measures of financing constraints, Quarterly Journal of Economics, 112, 169-215.

Konings, J.; Rizov, M.; Vandenbussche, H. (2003) Investment and financial constraints in transition economies: Micro evidence from Poland, the Czech Republic, Bulgaria and Romania, Economics Letters, 78, 253-258.

Kunt, A.; Maksimovic, V. (2002) Funding growth in bank-based and market-based financial systems: evidence from firm-level data, Journal of Financial Economics, 65, 337-363.

Lin, Y. (2007) The cash flow sensitivity of cash: evidence from Taiwan, Applied Financial Economics, 17, 1013-1024.

Manole, V.; Spatareanu, M. (2010) Exporting, capital investment and financial constraints, Review of World Economics, 146, 23-37.

Manova, K. (2010) Credit constraints, heterogeneous firms and international trade, NBER Working Paper 14531.

Melitz, M. J. (2003) The impact of trade on intra-industry reallocations and aggregate industry productivity, Econometrica, 71, 1695-1725.

Minetti, R.; Zhu, S. (2011) Credit constraints and firm export: Microeconomic evidence from Italy, Journal of International Economics, 83, 109-125.

Oliveira, B.; Fortunato, A. (2006) Firm growth and liquidity constraints: A dynamic analysis, Small Business Economics, 27, 139-156.

Popov, A.; Ongena, S. (2011) Interbank market integration, loan rates, and firm leverage, Journal of Banking and Finance, 35, 544-559.

Silva, A. (2011a) The role of subsidies for exports: Evidence from Portuguese manufacturing firms, GEE Papers no. 0035. Gabinete de Estratégia e Estudos, Ministério da Economia e da Inovação.

Silva, A. (2011b) Financial constraints and exports: evidence from Portuguese manufacturing firms, FEP Working Papers no. 402. Universidade do Porto, Faculdade de Economia do Porto.

Silva, F.; Carreira, C. (2010) Measuring firms' financial constraints: Evidence for Portugal through different approaches, Estudos do GEMF 15/2010. Coimbra, GEMF, University of Coimbra.

Silva, F.; Carreira, C. (2011) Financial constraints and firm dynamics: Lessons from the Portuguese economy during a period of integration, in Radovic-Markovic M., Redzepagiz S., Andrade J. and Teixeira P. (eds.), Serbia and the European Union: Economic lessons from the new member states, Coimbra, GEMF, University of Coimbra-Faculty of Economics, and Institute of Economic Sciences Belgrade, 185-199.

Whited, T. M., (1992) Debt, liquidity constraints, and corporate investment: Evidence from panel data, Journal of Finance, 47, 1425-1460. 
Size (S): Computed as log inflation-adjusted assets (deflation through the GDP deflator)

Investment (I | invest): Measured as additions to plant, property and equipment- gross investment.

Output $(Y \mid y)$ : Measured as total sales and services.

Cash-flow (CF | cf): Computed as net income before taxes plus depreciation.

Cash stock (CS | cs): Measured as total cash holdings.

Investment Opportunities $(\Delta Y \mid \Delta y)$ : Since we do not have financial markets information that would allow us to compute Tobin's $Q$, we use sales growth to proxy for investment opportunities.

Debt and equity issuances (ISS): Sum of debt and equity issuances. For the year 2001 equity issuances are reported as missing. The reason lies in legal changes that took place with the introduction of the Euro (most firms adjusted their equity not necessarily meaning issuing equity).

Non-cash net working capital (NWK | nwk): Difference between non-cash current assets and current liabilities.

Variation of interest paid $(\Delta / N T)$ : Variation of interest paid by firms, that may also reflect a firmspecific rating, scaled by total assets.

Financial investments (Finl): Firms' financial investments, scaled by total assets.

Benchmark interest rate (R): Annualised Euribor and Lisbor at 3 months with adjusted Lisbor by the mean difference in common years. We needed to compute our own series by joining two series made available by Banco de Portugal (Euribor for the period after the introduction of the Euro and Lisbor for the period before). The same change in monetary policy decision making, that accompanied the introduction of the Euro led to significant difficulties in finding comparable benchmark interest rates for the periods before and after 2000. Accordingly we focus on the interbank interest rate. Additionally we focus on the 3 months rate in order to avoid capturing the expectations incorporated in longer period rates. such as 1 year.

Degree of openness to foreign markets (OPEN): Score that captures the degree of openness of firms to foreign markets that in its turn is obtained by the sum of export and import intensity (normalized by sales) divided by 2. A firm scores 1 (no) if it is closed and 4 (yes) if open. Scores 2 (low) and 3 (high) are obtained by dividing open firms (score 4) at the mean degree of openness. Initially we divided firms into terciles by their degree of openness, however the use of terciles implies that a significant number of non exportinglimporting firms are included in the second tercile (about $40 \%$ of firms rely solely on the domestic market).

Export intensity (EXP): Total exports to the EU divided by total sales. Export intensity scores are obtained in the same manner as openness scores (described above).

Import intensity (IMP): Total imports from the EU divided by total sales. Import intensity scores are obtained in the same manner as openness scores (described above).

All variables of interest were winsorized at $1 \%$ level in order to avoid problems with outliers in the estimation procedures. Deflators used include the Industrial Production Price Index and Labour Cost Index, both drawn from INE, and the GDP deflator, drawn from the Portuguese Central Bank (BdP). Nevertheless, no deflators were used when a variable was constructed as a ratio of two nominal values (normalized). In such cases we assume that the price growth rates are homogeneous. All variables in low caps result from a normalization procedure (the variable of interest is divided by total assets). Real GDP growth (Euro 16 area) as well as unemployment rates were obtained from Eurostat.

The data is representative, at the sectoral and industrial levels, of the Portuguese economy. We 
have information on the disaggregated CAE rev. 2.1 industrial classification at the 5-digit level (Portuguese classification system). All industries are present in the dataset, even though we exclude the agricultural sector and the financial services industry for reasons explained in section 3.

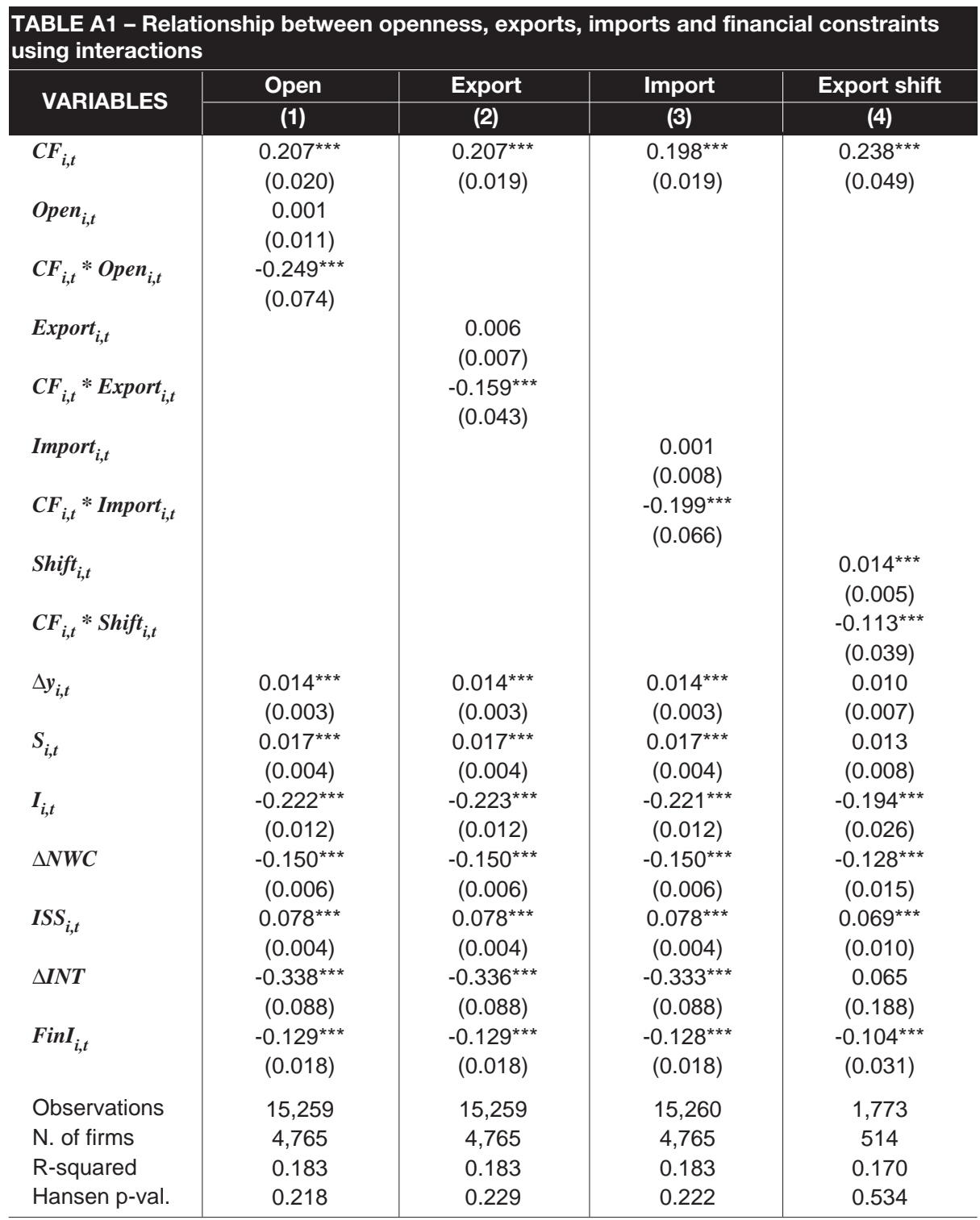

Notes: Regression of equation (1) with interaction terms for cash-flow and degree of openness, export intensity and import intensity (columns 1-3, respectively), as well as with a binary indicator for firms before and after shifting to export activity (column 4). All regressions include industry dummies (2-digit CAE rev.2.1). Robust standard errors in parentheses. ${ }^{* * *}{ }^{* *}$, and * denote statistical significance at the $.01, .05$, and .10 levels, respectively. Tables with confidence intervals and further test statistics available from the authors upon request. 